\title{
Implications of carbon monoxide bias for methane lifetime and atmospheric composition in chemistry climate models
}

\author{
S. A. Strode ${ }^{1,2}$, B. N. Duncan ${ }^{2}$, E. A. Yegorova ${ }^{2,3, a}$, J. Kouatchou ${ }^{2,4}$, J. R. Ziemke ${ }^{2,5}$, and A. R. Douglass ${ }^{2}$ \\ ${ }^{1}$ GESTAR, Universities Space Research Association, Columbia, MD, USA \\ ${ }^{2}$ NASA Goddard Space Flight Center, Greenbelt, MD, USA \\ ${ }^{3}$ Earth System Science Interdisciplinary Center, College Park, MD, USA \\ ${ }^{4}$ Science Systems and Applications Inc., Lanham, MD, USA \\ ${ }^{5}$ GESTAR, Morgan State University, Baltimore, MD, USA \\ anow at: Nuclear Regulatory Commission, Rockville, MD, USA \\ Correspondence to: S. A. Strode (sarah.a.strode@nasa.gov)
}

Received: 1 June 2015 - Published in Atmos. Chem. Phys. Discuss.: 27 July 2015

Revised: 28 September 2015 - Accepted: 12 October 2015 - Published: 23 October 2015

\begin{abstract}
A low bias in carbon monoxide (CO) at northern high and mid-latitudes is a common feature of chemistry climate models (CCMs) that may indicate or contribute to a high bias in simulated $\mathrm{OH}$ and corresponding low bias in methane lifetime. We use simulations with $\mathrm{CO}$ tagged by source type to investigate the sensitivity of the $\mathrm{CO}$ bias to $\mathrm{CO}$ emissions, transport, global mean $\mathrm{OH}$, and the hemispheric asymmetry of $\mathrm{OH}$. We also investigate how each of these possible contributors to the $\mathrm{CO}$ bias affects the methane lifetime. We find that the use of specified meteorology alters the distribution of CO compared to a free-running CCM simulation, improving the comparison with surface observations in summer. Our results also show that reducing the hemispheric asymmetry of $\mathrm{OH}$ improves the agreement of simulated $\mathrm{CO}$ with observations. We use simulations with parameterized $\mathrm{OH}$ to quantify the impact of known model biases on simulated $\mathrm{OH}$. Removing biases in ozone and water vapor as well as reducing Northern Hemisphere $\mathrm{NO}_{x}$ does not remove the hemispheric asymmetry in $\mathrm{OH}$, but it reduces global mean $\mathrm{OH}$ by $18 \%$, bringing the simulated methane lifetime into agreement with observation-based estimates.
\end{abstract}

\section{Introduction}

Carbon monoxide (CO) is an ozone precursor and a major sink of the hydroxyl radical $(\mathrm{OH})$ in the troposphere (Logan et al., 1981; Spivakovsky et al., 2000). Consequently, CO indirectly impacts climate by increasing tropospheric ozone where sufficient $\mathrm{NO}_{x}$ is present and increasing the lifetimes of methane and other short-lived greenhouse gases (GHGs), as well as eventually oxidizing to $\mathrm{CO}_{2}$ (e.g., Prather, 1996; IPCC, 1990). The effect of $\mathrm{CO}$ on $\mathrm{OH}$ also leads to impacts on oxidation of $\mathrm{SO}_{2}$ to sulfate, providing another climate forcing (Shindell et al., 2009). Previous studies calculated global warming potentials due to these effects using box models (Daniel and Solomon, 1998), 2-dimensional models (Fuglestvedt et al., 1996; Johnson and Derwent, 1996), or 3dimensional models (Derwent et al., 2001; Fry et al., 2012, 2013; Berntsen et al., 2005; Shindell et al., 2009). Since neither $\mathrm{CO}$ nor ozone is well mixed in the atmosphere, the location of the $\mathrm{CO}$ perturbation affects its climate impact. $\mathrm{CO}$ emissions in the tropics have a greater impact on ozone radiative forcing than emissions at high latitudes (Bowman and Henze, 2012) due the intense photochemistry in the tropics as well as the presence of deep convection, which can loft ozone precursors to the upper troposphere where the ozone radiative forcing is greatest (Fry et al., 2013; Naik et al., 2005).

While a large number of modeling studies have investigated the sources, transport, and distribution of $\mathrm{CO}$, global models often show major biases compared to observations. A study of 26 atmospheric chemistry models found that the simulated $\mathrm{CO}$ was biased low in the extratropical Northern Hemisphere (NH; Shindell et al., 2006) compared to satellite observations from MOPITT (Measurements of Pollution in the Troposphere; Emmons et al., 2004) and surface ob- 
servations, especially during spring. Shindell et al. (2006) attribute this bias primarily to an underestimate in $\mathrm{NH} \mathrm{CO}$ emissions, particularly from Asia. Monks et al. (2015) found that Arctic CO is biased low in the multi-model POLARCAT Model Intercomparison Project (POLMIP) and identified differences in global $\mathrm{OH}$ concentrations as a major driver of the inter-model differences in Arctic CO. The multi-model mean of the Atmospheric Chemistry and Climate Model Intercomparison Project (ACCMIP) simulations also shows a negative bias compared to both MOPITT and surface observations in the northern extratropics (Naik et al., 2013). Naik et al. (2013) found that ACCMIP models underestimate the methane and methyl chloroform lifetimes compared to the observation-based estimates of Prinn et al. (2005) and Prather et al. (2012) and produce a high bias in the NH to Southern Hemisphere ( $\mathrm{SH}$ ) ratio of $\mathrm{OH}$, consistent with the underestimate of $\mathrm{NH} \mathrm{CO}$. A recent comparison of simulated and observed methyl chloroform levels also indicates that the $\mathrm{NH} / \mathrm{SH} \mathrm{OH}$ ratio is $0.97 \pm 0.12$ rather than the value of 1.28 calculated by the ACCMIP models (Patra et al., 2014). However, $\mathrm{OH}$ and $\mathrm{CO}$ are major losses for each other, complicating the determination of how much $\mathrm{CO}$ bias drives $\mathrm{OH}$ bias versus $\mathrm{OH}$ bias driving $\mathrm{CO}$ bias.

Previous studies used models to examine the consistency of $\mathrm{CO}$ emission estimates with surface and satellite observations of $\mathrm{CO}$ concentration. A modeling study by Duncan et al. (2007a) showed that their model compared well to observations in the NH extratropics, but they point out that a low bias in their model emissions may have been compensated for by an assumption made in their simplified chemical scheme that non-methane hydrocarbons (NMHCs) oxidize to $\mathrm{CO}$ immediately upon release; this assumption is valid during summer months for short-lived NMHCs (e.g., alkenes, isoprene) but is not valid in winter and spring for longerlived NMHCS (e.g., alkanes). Stein et al. (2014) found that a combination of higher winter traffic emissions from North America and Europe and reduced dry deposition during boreal winter improved the agreement between simulated and observed $\mathrm{CO}$. These findings are consistent with inversions of MOPITT CO data that show that including greater winter emissions from the $\mathrm{NH}$ reduces the negative bias in springtime CO at northern latitudes (Petron et al., 2004).

Kopacz et al. (2010) inverted CO observations from multiple satellites and concluded that northern midlatitude $\mathrm{CO}$ sources were underestimated in winter, and that implementing large seasonal variations in emissions improved model agreement with observations. The inversion study of Fortems-Cheiney et al. (2011) also found that the posterior $\mathrm{CO}$ emissions had large seasonality in the $\mathrm{NH}$, with the maximum occurring in spring. However, the source strengths estimated by inversions are influenced by factors such as model transport (Arellano and Hess, 2006) and the concentrations of other species that interact with $\mathrm{CO}$ through $\mathrm{OH}$ chemistry (Pison et al., 2009; Muller and Stavrakou, 2005; Jones et al., 2009). Given the complexities of the nonlinear $\mathrm{CO}-\mathrm{OH}-\mathrm{CH}_{4}$ system, we conduct a series of sensitivity studies in which we adjust individual inputs to a chemistry climate model (CCM) one at a time.

Uncertainty in the tropospheric burden and distribution of $\mathrm{OH}$ leads to further uncertainty in the $\mathrm{CO}$ budget. Hooghiemstra et al. (2011) found that higher $\mathrm{NH} \mathrm{OH}$ concentrations led to higher anthropogenic $\mathrm{CO}$ emissions in their inversion study, while lower $\mathrm{OH}$ concentrations over tropical land masses and the SH led to lower biomass burning $\mathrm{CO}$ emissions and less CO from NMHCs. Duncan et al. (2007a) found that reducing $\mathrm{OH}$ by $20 \%$ globally improved the comparison of their simulated $\mathrm{CO}$ with surface observations in some locations but degraded the comparison at other locations. Patra et al. (2014) suggested that top-down emission estimates from models with much higher $\mathrm{OH}$ in the $\mathrm{NH}$ than $\mathrm{SH}$ likely overestimate $\mathrm{NH}$ countries' emissions of $\mathrm{CO}$ and other reactive species. Mao et al. (2013) found that including conversion of $\mathrm{HO}_{2}$ to $\mathrm{H}_{2} \mathrm{O}$ on aerosols reduced $\mathrm{OH}$ concentrations in a global model, correcting much of the negative model bias in the extratropical $\mathrm{NH}$, with the largest $\mathrm{CO}$ increase occurring in spring.

Accurate simulation of tropospheric $\mathrm{OH}$ requires models to represent multiple drivers of atmospheric $\mathrm{OH}$ concentrations. Holmes et al. (2013) found that temperature, water vapor, stratospheric ozone, and emissions from biomass burning and lightning could together explain most of the interannual variability in methane lifetime against $\mathrm{OH}$. Duncan and Logan (2008) found that changes in the ozone column were a major driver of OH variability over 1988-1997. Murray et al. (2013) found that lightning was more important for OH variability over 1998-2006, when there was less variability in the overhead ozone column. Murray et al. (2014) found that, on glacial-interglacial timescales, $\mathrm{OH}$ concentrations were proportional to the tropospheric ozone photolysis rate, specific humidity, and reactive nitrogen emissions, and inversely proportional to $\mathrm{CO}$ emissions. The present study investigates the sensitivity of simulated $\mathrm{CO}$ and methane lifetime to biases in some of these processes.

Understanding the causes and implications of $\mathrm{CO}$ bias in CCMs is important for climate prediction as it may indicate or contribute to biases in methane and ozone and their respective radiative forcing contributions. The goal of this study is to quantify the relationship of the extratropical NH $\mathrm{CO}$ bias seen in CCMs with bias in oxidant concentrations and methane lifetime. Our focus is primarily on NH spring and summer, when the $\mathrm{NH} \mathrm{CO}$ bias is large. We use the GEOS-5 Chemistry Climate Model (GEOSCCM) to investigate how attributing a CCM's $\mathrm{CO}$ bias to $\mathrm{CO}$ emissions versus $\mathrm{OH}$ chemistry impacts ozone and methane lifetime. We also quantify the contribution of model biases in other constituents such as ozone and water vapor to the simulated $\mathrm{OH}$ and $\mathrm{CO}$ distributions and methane lifetime. 


\section{Methods}

\subsection{Constituent observations and assimilated fields}

Our primary constraint on the model $\mathrm{CO}$ distribution comes from surface observations from the NOAA Global Modeling Division (GMD) network (Novelli and Masarie, 2014). We use the monthly mean data. The MOPITT instrument on the Terra satellite provides additional constraints on the $\mathrm{CO}$ distribution. MOPITT provides almost global coverage every 3 days from March 2000 to present (Edwards et al., 2004). We use the level $3 \mathrm{CO}$ column data from the MOPITT version 5 thermal infrared (TIR) product (Deeter et al., 2011, 2013).

Observations of tropospheric ozone are important for constraining the source of OH. Ziemke et al. (2011) created a climatology of tropospheric column ozone (TCO) based on the difference between the stratospheric column ozone (SCO) from the Microwave Limb Sounder (MLS) and total ozone column data from the Ozone Monitoring Instrument (OMI). The observations are cloud-filtered, so there is sensitivity throughout the troposphere, although there is some reduction in retrieval efficiency in the lower troposphere. We use the TCO product for 2004-2010 to constrain the tropospheric ozone column. Stratospheric ozone is also important for constraining the $\mathrm{OH}$ source due to its effect on photolysis (Rohrer and Berresheim, 2006). We use the Global Modeling and Assimilation Office (GMAO) ozone assimilation product for 2005-2010 to constrain stratospheric ozone concentrations. The GMAO assimilated ozone product, described in Ziemke et al. (2014) and Wargan et al. (2015), is a gridded product that was created by ingesting MLS ozone profiles and OMI total column ozone into the GEOS-5 assimilation system.

Water vapor is another important influence on $\mathrm{OH}$ concentrations. We use specific humidity from the ModernEra Retrospective Analysis for Research and Applications (MERRA) (Rienecker et al., 2011).

\subsection{Model and methodology}

Our analysis uses the GEOSCCM to assess possible causes and impacts of $\mathrm{CO}$ and $\mathrm{OH}$ bias. After spin-up, we conduct a series of time slice simulations of 1999-2009 with fixed emissions using observed sea surface temperatures (SSTs) to drive the CCM meteorology, and then average our results over all years of the time slice. All simulations use the Fortuna version of GEOS-5 (Molod et al., 2012) and have $2^{\circ}$ latitude by $2.5^{\circ}$ longitude horizontal resolution and 72 vertical levels.

We use a series of sensitivity studies to analyze the role of $\mathrm{CO}$ emissions, $\mathrm{OH}$ concentrations, and transport. Two methods are used to examine the sensitivity of $\mathrm{CO}$ concentrations to $\mathrm{CO}$ emissions from different sources: scaling up the $\mathrm{CO}$ emissions, and scaling up CO tracers tagged by source. We quantify the sensitivity of $\mathrm{CO}$ to $\mathrm{OH}$ concentrations by ap- plying scaling factors to the $\mathrm{OH}$ field. We analyze the sensitivity to transport by comparing a free-running CCM simulation with a simulation that has prescribed meteorology. Several different chemistry options within the GEOSCCM framework are used to isolate specific processes. We describe each chemistry option and associated experiments below and in Table 1.

\subsubsection{GMI chemistry option}

GEOSCCM integrates the chemistry mechanism of the Global Modeling Initiative (GMI) chemistry and transport model (CTM; Duncan et al., 2007b; Strahan et al., 2007) into the GEOS-5 Atmospheric GCM (AGCM). The GMI chemistry includes a comprehensive mechanism of tropospheric and stratospheric chemistry, including 117 species and over 400 reactions. The reference simulation for this study, hereafter called RefGMI, is the year 2000 time slice simulation conducted for the ACCMIP intercomparison. The configuration of the ACCMIP simulations is described in Lamarque et al. (2013). The biases in CO and methane lifetime seen in the GEOSCCM simulation are similar to those seen in the ACCMIP multi-model mean (Naik et al., 2013). Consequently, our analyses of bias in the GEOSCCM are likely applicable to other CCMs as well. We use the GMI chemistry option to quantify the impact of changes in $\mathrm{CO}$ emissions on methane, $\mathrm{OH}$, and ozone.

\subsubsection{CO-only option}

GEOSCCM includes a CO-only option to "tag" $\mathrm{CO}$ according to source type or location (Bian et al., 2010). This simplified chemistry option allows us to separate the contributions of different $\mathrm{CO}$ sources and to quantify the impact of a specific change in $\mathrm{OH}$. In this chemistry option, the loss of $\mathrm{CO}$ is calculated based on prescribed $\mathrm{OH}$ fields, so changes in $\mathrm{CO}$ do not feed back onto $\mathrm{OH}$. Our reference tagged$\mathrm{CO}$ simulation, called RefCOonly, uses monthly $\mathrm{OH}$ fields archived from the RefGMI simulation, and the CO sources from methane and isoprene oxidation are calculated using monthly methane and isoprene fields archived from RefGMI as well. Emissions and other forcings are chosen to parallel the RefGMI simulation; however, the CO-only option includes an amplification factor for anthropogenic and biomass burning $\mathrm{CO}$ emissions to account for the absence of coemitted NMHCs (Duncan et al., 2007a). We use the CO-only option to calculate the influence of specific sources on $\mathrm{CO}$ concentrations, and to isolate the impact of specific changes in $\mathrm{OH}$ on $\mathrm{CO}$.

The GEOSCCM includes an option to constrain the meteorology with MERRA or any GMAO assimilation product. The simulation is pulled towards the MERRA analysis through application of an incremental analysis update (Bloom et al., 1996), calculated every 6 hours from comparison of the simulation with the analysis. We conduct a 
Table 1. Description of reference and sensitivity simulations used in this study with each chemistry option.

\begin{tabular}{|c|c|c|}
\hline Simulation & Description & Key result \\
\hline \multicolumn{3}{|c|}{ GMI chemistry simulations } \\
\hline RefGMI* & ACCMIP time slice simulation for 2000 & CO biased low at high latitudes \\
\hline GMI-HiEmis & Increased CO emissions compared to RefGMI & Regional CO biases compared to MOPITT \\
\hline \multicolumn{3}{|l|}{ CO-only simulations } \\
\hline RefCOonly* & Tagged-CO version of RefGMI & Similar CO biases to RefGMI \\
\hline COonlyLowNHOH & NH OH uniformly decreased by $20 \%$ & $\begin{array}{l}\text { Improves agreement with GMD CO observa- } \\
\text { tions }\end{array}$ \\
\hline COonlySD & $\begin{array}{l}\text { Meteorology constrained by MERRA (speci- } \\
\text { fied dynamics) }\end{array}$ & $\begin{array}{l}\text { Improves agreement with GMD CO observa- } \\
\text { tions in summer }\end{array}$ \\
\hline \multicolumn{3}{|l|}{$\mathrm{CO}-\mathrm{OH}$ simulations } \\
\hline RefCO-OH* & Parameterized $\mathrm{OH}$ version of RefGMI & Lower OH than RefGMI \\
\hline CO-OHSensTCO & $\begin{array}{l}\text { Tropospheric ozone column adjusted to match } \\
\text { OMI/MLS TCO }\end{array}$ & $2.5 \%$ increase in $\mathrm{CH}_{4}$ lifetime \\
\hline $\mathrm{CO}-\mathrm{OHSensStO} 3$ & $\begin{array}{l}\text { Stratospheric } \mathrm{O}_{3} \text { adjusted to match assimilated } \\
\mathrm{O}_{3}\end{array}$ & $2.4 \%$ increase in $\mathrm{CH}_{4}$ lifetime \\
\hline CO-OHSensQ & $\begin{array}{l}\text { Tropospheric water vapor adjusted based on } \\
\text { MERRA }\end{array}$ & $5.7 \%$ increase in $\mathrm{CH}_{4}$ lifetime \\
\hline CO-OHSensNOx & $30 \%$ decrease in $\mathrm{NH} \mathrm{NO}_{x}$ concentrations & $\begin{array}{l}3.5 \% \text { increase in } \mathrm{CH}_{4} \text { lifetime; } \mathrm{OH} \text { asymmetry } \\
\text { reduced but not eliminated }\end{array}$ \\
\hline CO-OHSensAll & $\begin{array}{l}\text { Tropospheric and stratospheric } \mathrm{O}_{3} \text {, water vapor, } \\
\text { and } \mathrm{NH} \mathrm{NO}_{x} \text { all adjusted }\end{array}$ & $\begin{array}{l}15 \% \text { increase in } \mathrm{CH}_{4} \text { lifetime; } \mathrm{OH} \text { asymmetry } \\
\text { reduced but not eliminated }\end{array}$ \\
\hline
\end{tabular}

* Reference simulation

CO-only simulation with specified dynamics from MERRA, which we refer to as COonlySD, where "SD" stands for "specified dynamics". The COonlySD simulation has the same emissions and $\mathrm{OH}$ field as RefCOonly, but the tracer transport will differ between the two simulations.

\subsubsection{CO-OH option}

A third chemistry option within the GEOSCCM is the COOH option (Duncan et al., 2000, 2007a). This chemistry option is of intermediate complexity between the GMI and tagged-CO options. This option is similar to the CO-only option except that $\mathrm{OH}$ is calculated interactively, providing a feedback between $\mathrm{CO}$ and $\mathrm{OH}$ concentrations. In our reference simulation with this option, RefCO-OH, chemistry inputs to the parameterization of $\mathrm{OH}$ such as ozone, $\mathrm{NO}_{x}, \mathrm{CH}_{4}$, and NMHC concentrations are prescribed from the archived monthly output of the RefGMI simulation. The temperature, water vapor, and irradiance-related variables input to the parameterization are calculated within the CCM. Since the parameterization was only designed to provide tropospheric $\mathrm{OH}$ values, we use the results of the parameterization from the surface to $300 \mathrm{hPa}$, and archived $\mathrm{OH}$ fields taken from the RefGMI simulation above $300 \mathrm{hPa}$. The CO emission amplification factors are adjusted slightly downward compared to the CO-only simulation to bring the RefCO-OH simula- tion into better agreement with the RefGMI simulation. We use the $\mathrm{CO}-\mathrm{OH}$ option to examine how biases in a particular model field such as ozone affect $\mathrm{OH}$ and $\mathrm{CO}$ concentrations.

\section{Results}

We use the three chemistry options of the GEOSCCM to separate the contributions of emissions, chemistry, and transport to model bias in $\mathrm{CO}$ and methane lifetime. In Sect. 3.1, we compare the $\mathrm{CO}$ distribution simulated by the three options to observations and discuss the consistencies and differences between simulations. We analyze the impacts of increasing emissions, decreasing $\mathrm{OH}$, and changing model transport on the $\mathrm{CO}$ distribution in Sect. 3.2, and we examine how changing $\mathrm{CO}$ emissions affects ozone and $\mathrm{OH}$ in Sect. 3.3. In Sect. 3.4, we investigate the contribution of known model biases to simulated $\mathrm{OH}$ and methane lifetimes. Table 1 summarizes the key results of each of the sensitivity studies.

\subsection{Comparison of $\mathrm{OH}$ and $\mathrm{CO}$ in the reference simulations and observations}

This section presents a comparison of $\mathrm{CO}$ and $\mathrm{OH}$ distributions from the RefGMI, RefCOonly, and RefCO-OH simulations to each other and to observations. The choice of chemistry option affects the $\mathrm{CO}$ and $\mathrm{OH}$ distributions pro- 

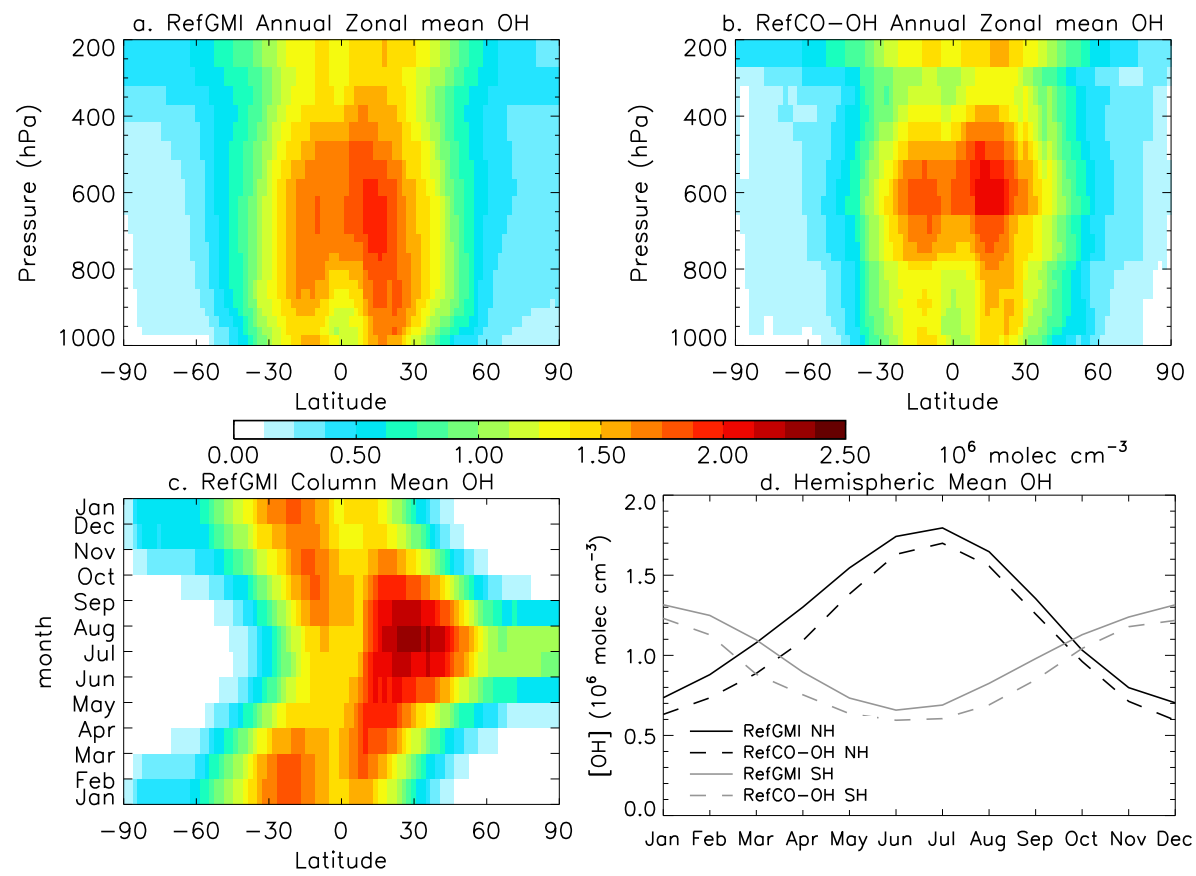

Figure 1. Simulated annual zonal mean OH concentration for the RefGMI (a) and RefCO-OH simulations (b) averaged over 1999-2009. (c) The annual cycle of the pressure-weighted column mean $\mathrm{OH}$ by latitude from the RefGMI simulation. The column is averaged between the surface and $200 \mathrm{hPa}$. (d) The annual cycle of hemispheric mean OH from the RefGMI (solid lines) and RefCO-OH (dashed lines) simulations for the Northern Hemisphere (black lines) and Southern Hemisphere (gray lines).
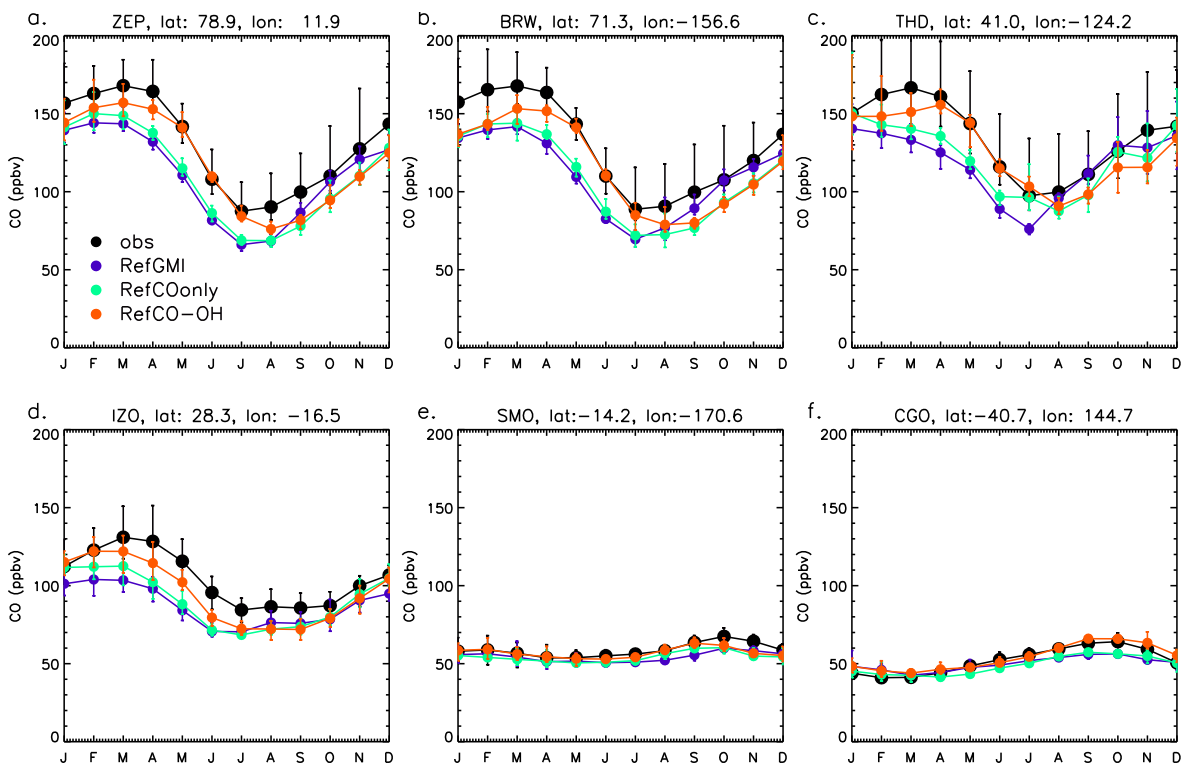

Figure 2. Monthly mean GMD observations (black) and results from the RefGMI (purple), RefCOonly (green), and RefCO-OH (orange) simulations. Circles and error bars represent the mean and min-max range, respectively, for 1999-2009. The GMD sites are as follows: (a) Ny-Alesund, Svalbard (ZEP, 78. $\left.9^{\circ} \mathrm{N}, 11.9^{\circ} \mathrm{E}\right)$; (b) Barrow, Alaska (BRW, 71.3 $\left.{ }^{\circ} \mathrm{N}, 156.6^{\circ} \mathrm{W}\right)$; (c) Trinidad Head, California (THD, 41.0 $0^{\circ} \mathrm{N}$, $\left.124.2^{\circ} \mathrm{W}\right)$; (d) Izana, Tenerife, Canary Islands (IZO, 28.3 $\left.{ }^{\circ} \mathrm{N}, 16.5^{\circ} \mathrm{W}\right)$; Tutuila, American Samoa (SMO, $\left.14.2^{\circ} \mathrm{S}, 170.6^{\circ} \mathrm{W}\right)$; and $(\mathbf{e}) \mathrm{Cape}$ Grim, Tasmania $\left(\mathrm{CGO}, 40.7^{\circ} \mathrm{S}, 144.7^{\circ} \mathrm{E}\right)$. 

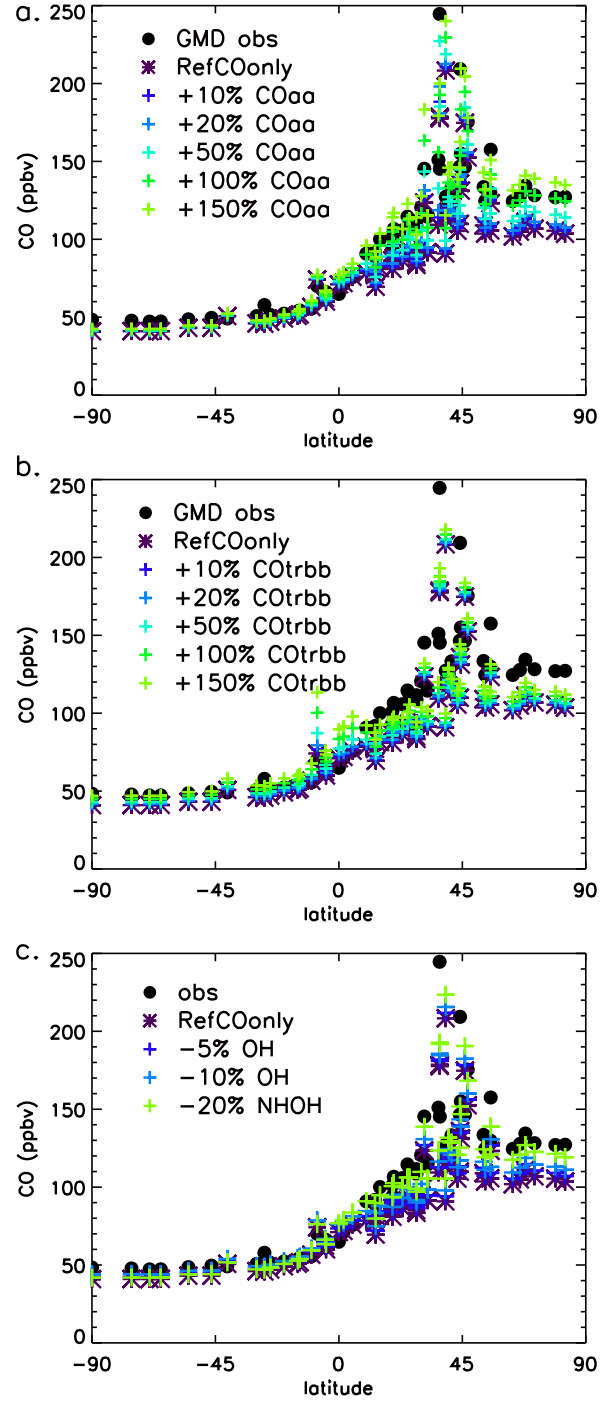

Figure 3. Latitudinal distribution of $\mathrm{CO}$ observations from the GMD network (black circles) and simulated CO from the RefCOonly simulation (purple stars) averaged over March-August. Blue-green + signs indicate the effect of (a) increasing the Asian anthropogenic $\mathrm{CO}$ tracer, (b) increasing the tropical biomass burning $\mathrm{CO}$ tracer, and (c) decreasing $\mathrm{OH}$ globally by 5 or $10 \%$, or decreasing $\mathrm{NH} \mathrm{OH}$ by $20 \%$.

duced by the GEOSCCM. Annually averaged OH is higher in the RefGMI simulation in both hemispheres (Table 2; Fig. 1). High $\mathrm{OH}$ values extend further down in the troposphere in RefGMI than in RefCO-OH. Global annual mean mass-weighted tropospheric $\mathrm{OH}$ is approximately $7 \%$ lower in RefCO-OH than in RefGMI, but the NH / SH OH ratio is marginally higher: 1.22 instead of 1.19. Prather et al. (2012) report an observation-based estimate of methane lifetime of $9.1 \pm 0.9$ years, and a methane lifetime against tropospheric $\mathrm{OH}$ of $11.2 \pm 1.3$ years. The lifetimes of methyl chloroform and methane against tropospheric $\mathrm{OH}$ in the RefGMI sim-
Table 2. Tropospheric OH concentrations and lifetimes against oxidation by tropospheric $\mathrm{OH}$.

\begin{tabular}{|c|c|c|c|}
\hline & RefGMI & $\begin{array}{l}\text { GMI- } \\
\text { HiEmis }\end{array}$ & $\begin{array}{c}\text { RefCO- } \\
\text { OH }\end{array}$ \\
\hline Global mean $\mathrm{OH}\left(10^{6}\right.$ molec $\left.\mathrm{cm}^{-3}\right)$ & 1.14 & 1.11 & 1.05 \\
\hline $\mathrm{SH} \mathrm{OH}\left(10^{6}\right.$ molec $\left.\mathrm{cm}^{-3}\right)$ & 1.03 & 1.02 & 0.943 \\
\hline $\mathrm{NH} \mathrm{OH}\left(10^{6}\right.$ molec $\left.\mathrm{cm}^{-3}\right)$ & 1.22 & 1.18 & 1.15 \\
\hline NH / SH OH & 1.19 & 1.16 & 1.22 \\
\hline $\mathrm{CH}_{4}$ lifetime (years) & 9.65 & 9.89 & 10.5 \\
\hline $\mathrm{CH}_{3} \mathrm{CCl}_{3}$ lifetime (years) & 5.91 & 6.06 & 6.39 \\
\hline
\end{tabular}

ulation are 5.9 and 9.6 years, respectively (Table 2). The lifetimes of methyl chloroform and methane against tropospheric $\mathrm{OH}$ in the RefCO-OH simulation are 6.4 and 10 years, respectively, within the uncertainty of the observationbased estimates. The seasonal cycles are similar in both simulations, but the difference in $\mathrm{NH} \mathrm{OH}$ is larger in the first half of the year than the second half (Fig. 1d). Consequently, when using the $\mathrm{CO}-\mathrm{OH}$ option, we present the changes due to a given factor rather than the absolute values of $\mathrm{CO}, \mathrm{OH}$, and methane lifetime for easier comparison with the other simulations.

Figure 2 shows the annual cycle of simulated $\mathrm{CO}$ and observations from six GMD sites selected to represent a range of latitudes. Observations are averaged over the period from 1999 to 2009, with the exception of Trinidad Head, which is averaged over 2002-2009. The RefGMI simulation (purple) is biased low at the $\mathrm{NH}$ sites, with the bias most prominent during the first half of the year, especially $\mathrm{NH}$ spring. The simulation shows less bias at the SH sites, but some negative bias is evident in SH spring. The RefCOonly simulation (green) shows similar results to RefGMI, including a large negative bias in the $\mathrm{NH}$ in spring. Consequently, diagnosing the cause of bias in the RefCOonly simulation can provide insight into the bias in the RefGMI simulation.

The RefCO-OH simulation (orange) shows less springtime bias compared to observations than the RefGMI and RefCOonly simulations. However, its annual cycle is shifted later, resulting in more negative biases in SeptemberDecember at the higher northern latitudes. The difference between the RefCO-OH and the other two reference simulations is explained by the differences in the $\mathrm{OH}$ field calculated by the parameterization compared to that calculated by the GMI chemistry mechanism. In April, when the greater $\mathrm{NH}$ bias of the RefGMI simulation is most evident (Fig. 2), the RefGMI OH is markedly higher than the $\mathrm{OH}$ in RefCOOH (Fig. 1).

\subsection{Sensitivity of simulated CO to sources, $\mathrm{OH}$, and transport}

We conduct a series of sensitivity studies to examine possible causes of the bias in NH CO seen in the RefGMI and RefCOonly simulations during spring and summer. We focus 

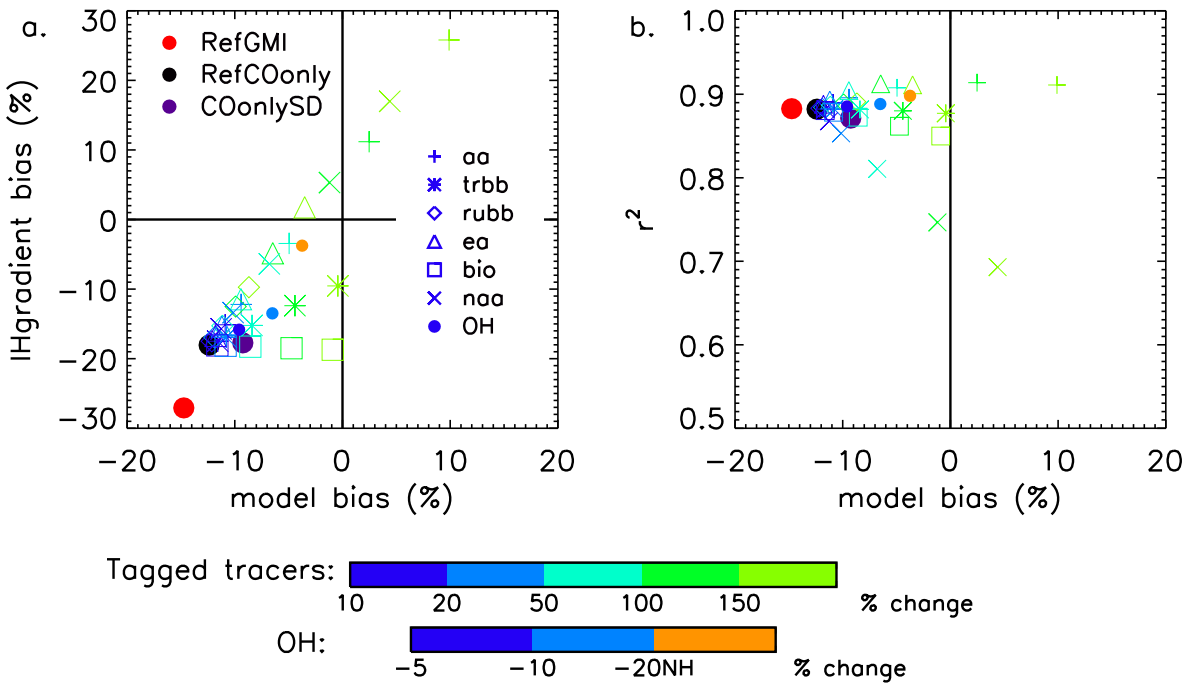

Figure 4. The impact of increasing the tagged-CO tracers for Asian anthropogenic (+), tropical biomass burning (stars), Russian biomass burning (diamonds), European anthropogenic (triangles), biogenic (squares), and North American anthropogenic (x) sources on (a) bias in the inter-hemispheric gradient versus global mean bias and (b) correlation versus global mean bias compared to GMD observations from March to May. Large circles represent the RefGMI (red), RefCOonly (black), and COonlySD (purple) simulations. Small circles show the impact of changing global or $\mathrm{NH} \mathrm{OH}$ in the RefCOonly simulation.
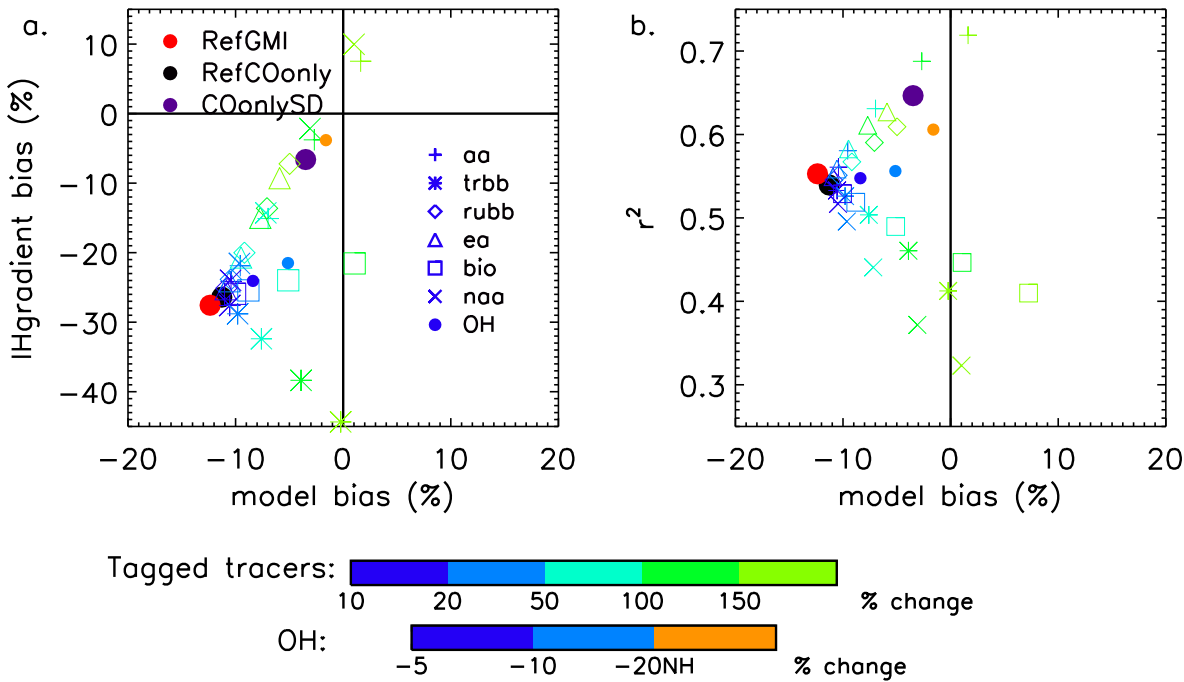

Figure 5. As in Fig. 4 but for June through August.

on spring, since it is the season with the largest bias in $\mathrm{NH}$ $\mathrm{OH}$ (Fig. 2), and contrast the spring results with those from summer, since the bias persists into summer despite seasonal differences in transport and chemistry.

\subsubsection{Sensitivity of CO-only simulations to sources and OH}

Adjusting the strength of midlatitude $\mathrm{CO}$ sources can reduce the bias in the interhemispheric $\mathrm{CO}$ gradient. We use COonly simulations to examine the impact of increasing specific sources of CO. Following the method of Strode and Paw- son (2013), we estimate the impact of increasing a particular source by increasing the tagged-CO tracer for that source and then re-computing total $\mathrm{CO}$. We impose increases of 10,20 , 50,100 , and $150 \%$ for each tagged tracer. Figure 3 shows how the increased Asian anthropogenic $\mathrm{CO}$ (COaa) or tropical biomass burning $\mathrm{CO}$ (COtrbb) alters the comparison between modeled $\mathrm{CO}$ and the GMD CO observations as a function of latitude taken as an average of March to August. Similar results are present for spring and summer individually. An increase in COaa of approximately $100 \%$ removes the negative bias at high-latitude sites but has little effect on the 

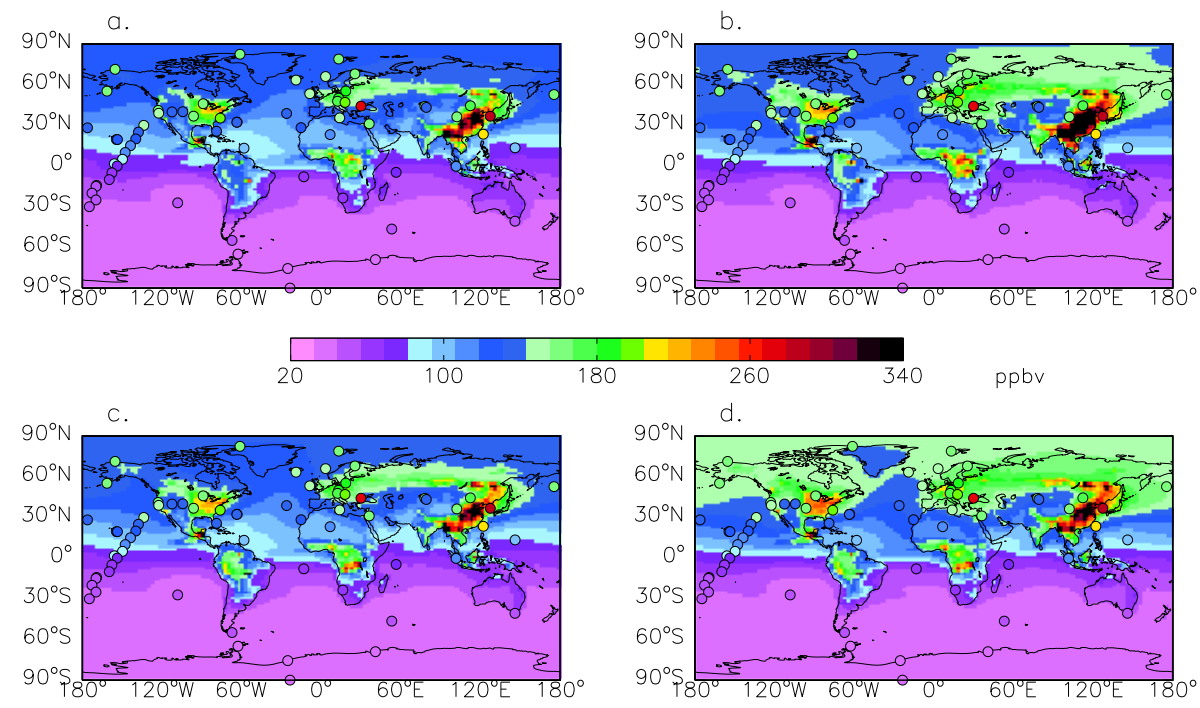

Figure 6. CO for March through May of 1999-2009 from the GMD observations (circles) overplotted on the surface CO from (a) RefGMI, (b) GMI-HiEmis, (c) RefCOonly, and (d) COonlyLowNHOH simulations.

small negative bias at low latitudes (Fig. 3a). CO transported southward from Asia encounters higher $\mathrm{OH}$ than that transported northward, leading to a shorter lifetime (Duncan and Logan, 2008). Increasing COtrbb improves the model agreement with observations at low latitudes but creates overestimates at some tropical sites while providing only a modest reduction in the high-latitude bias (Fig. 3b).

We examine the impact of reducing $\mathrm{OH}$ concentrations globally or only in the $\mathrm{NH}$ in our CO-only simulation and find that a large decrease in $\mathrm{NH} \mathrm{OH}$ is effective in reducing the high-latitude CO bias. Naik et al. (2013) found that the ACCMIP multi-model mean underestimated annual mean tropospheric $\mathrm{OH}$ by $5-10 \%$ globally. The $\mathrm{NH} / \mathrm{SH} \mathrm{OH}$ ratios in the ACCMIP multi-model mean and GEOSCCM ACCMIP simulation are 1.28 and 1.18 , respectively (Naik et al., 2013), compared to the Patra et al. (2014) estimate of $0.97 \pm 0.12$. Figure $3 \mathrm{c}$ shows that reducing $\mathrm{OH}$ throughout the year by $5-10 \%$ leads to a small increase in CO across all latitudes, yielding a small reduction in the bias compared to GMD observations. Decreasing $\mathrm{OH}$ by $20 \%$ in the $\mathrm{NH}$ only leads to a large improvement in high-latitude $\mathrm{CO}$ compared to observations, with only a small effect in the Southern Hemisphere.

\subsubsection{Impact of sources and $\mathrm{OH}$ on global mean and inter-hemispheric gradient bias in $\mathrm{CO}$}

We find that achieving zero bias in both the inter-hemispheric gradient (IHG) and the global mean would require changes in multiple emission sources. Figure 4 illustrates how changing the concentrations of several tagged-CO tracers, as well as $\mathrm{OH}$, impacts the global mean bias, IHG bias, and correlation $\left(r^{2}\right)$ of the simulated CO compared to the GMD observations for March through May. Increasing anthropogenic CO from Asia (COaa), Europe (COea), or North America (COnaa), or increasing Russian biomass burning (COrubb) reduces the bias in the IHG as well as in the global mean. Increasing CO from tropical biomass burning (COtrbb) leads to a smaller reduction in the IHG bias, while increasing $\mathrm{CO}$ from biogenic emissions (CObio) reduces the mean bias with little effect on the IHG (Fig. 4a). Consequently, increases in both groups of emissions are necessary to simultaneously remove the global mean bias and correct the IHG.

A similar analysis for June through August (Fig. 5) shows that increasing COaa, COea, COnaa, or COrubb can eliminate the majority of the bias in both the global mean and the IHG in summer. Increasing COrubb is more effective in summer than spring since boreal biomass burning emissions are larger in summer. In contrast to the spring results, increasing COtrbb in summer leads to greater bias in the IHG. This difference occurs because tropical biomass burning occurs primarily north of the Equator in March and April but shifts to the Southern Hemisphere in June, July, and August.

While increases in COaa, COea, COnaa, and COrubb show similar slopes for IHG versus global mean bias, increasing COnaa reduces the correlation with observations, whereas increasing the other sources yields a slight improvement in correlation (Figs. 4b, 5b). Increases in both COtrbb and CObio reduce the correlation with observations in summer, but the effect is also present for CObio in spring. We therefore exclude increases in COnaa and CObio in the rest of our study.

Figures 4 and 5 also show the impact of changing $\mathrm{OH}$. The sensitivity of $\mathrm{CO}$ to changes in $\mathrm{OH}$ is location dependent, with higher sensitivity in regions without strong local CO sources (Holloway et al., 2000). Reducing OH globally 
reduces both the IHG and global mean bias. However, reducing $\mathrm{OH}$ by $20 \%$ in the $\mathrm{NH}$ only yields a greater reduction in both biases as well as the greatest improvement in correlation. We refer to the simulation with the $20 \%$ decrease in $\mathrm{NH} \mathrm{OH}$ as COonlyLowNHOH.

\subsubsection{Impact of adjusting sources versus $\mathrm{NH} \mathrm{OH}$ on comparison to observations}

We next compare the impact of increasing emissions with that of reducing $\mathrm{NH} \mathrm{OH}$ by $20 \%$. We compare the COonlyLowNHOH scenario with a simulation called GMI-HiEmis that includes increased $\mathrm{CO}$ emissions, further described in Sect. 3.3. The RefCOonly simulation shows a similar surface CO distribution to RefGMI (Fig. 6a, c). The COonlyLowN$\mathrm{HOH}$ scenario (Fig. 6d) improves the agreement with the remote high-latitude sites compared to the RefCOonly simulation, but like the HiEmis case (Fig. 6b) it leads to an overestimate of $\mathrm{CO}$ concentrations over Europe and the eastern United States. Consequently, a combination such as reduced $\mathrm{NH} \mathrm{OH}$ and reduced emissions over the eastern USA is likely needed to reconcile the simulated $\mathrm{CO}$ with observations.

Sparse surface data makes it difficult to determine from comparison with GMD observations whether the higher $\mathrm{CO}$ seen in GMI-HiEmis and COonlyLowNHOH is realistic (Fig. 6), so we also compare the four simulations shown in Fig. 6 to the CO column from MOPITT. Both the RefGMI and RefCOonly simulations show a large negative bias in NH CO compared to MOPITT (Fig. 7a, c). The GMIHiEmis and COonlyLowNHOH simulations both reduce this negative bias (Fig. 7b, d), but the increased emissions of the GMI-HiEmis simulation lead to a greater overestimate of $\mathrm{CO}$ over east Asia and Indonesia. Furthermore, eliminating the increase in COea to reduce the high bias compared to surface observations over Europe and compensating with a larger adjustment in Asian CO would lead to an even greater bias over Asia compared to MOPITT.

\subsubsection{CO sensitivity to transport}

Transport, in addition to chemistry and emissions, plays a role in the IHG of CO. The simulations discussed so far are free-running CCM simulations driven by SSTs, since our goal is to understand the biases seen in CCM studies such as ACCMIP. Consequently, the simulated tracer transport is affected by any differences between the simulated and actual meteorology. We examine the sensitivity of the $\mathrm{CO}$ bias to model transport by comparing RefCOonly, which is a free-running CCM simulation, with the COonlySD simulation, which has year-specific meteorology from MERRA. The largest difference between the simulations occurs poleward of $30^{\circ} \mathrm{N}$ during July through October (Fig. 8a). The use of specified meteorology makes only a small difference in the global mean and IHG CO biases compared to surface observations in March-May (Fig. 4), but it leads to a large reduction in bias as well as improved spatial correlation with the GMD observations in June-August (Fig. 5). The biases in global mean $\mathrm{CO}$ and the CO IHG are -3.5 and $-6.6 \%$, respectively, in COonlySD, compared to -11 and $-26 \%$, respectively, in RefCOonly. More CO from Northern Hemisphere anthropogenic and boreal biomass burning sources remains in the lower troposphere and reaches the high latitudes in COonlySD, whereas more is transported to the upper troposphere in RefCOonly (Fig. 8b).

\subsection{Impact of increased $\mathrm{CO}$ emissions on ozone, $\mathrm{OH}$, and $\mathrm{CH}_{4}$ lifetime}

The tagged tracer results presented in Sect. 3.2.2 suggest that increasing $\mathrm{CO}$ emissions can improve the agreement with $\mathrm{CO}$ surface observations. However, increasing $\mathrm{CO}$ emissions will lead to feedbacks on $\mathrm{OH}, \mathrm{CH}_{4}$, and ozone that are not captured by the CO-only chemistry option. We therefore conduct a sensitivity simulation with the GMI chemistry option called GMI-HiEmis, which is identical to the RefGMI simulation except for an increase in $\mathrm{CO}$ emissions. Since trace gases in the GMI option of the GEOSCCM are radiatively coupled to the underlying GCM, altering emissions within this option produces feedbacks between $\mathrm{CO}$, ozone, $\mathrm{CH}_{4}$, and radiation and transport.

The results shown in Figs. 4 and 5 suggest that increasing $\mathrm{CO}$ from tropical biomass burning along with Asian anthropogenic, European anthropogenic, and Russian biomass burning $\mathrm{CO}$ can eliminate both the IHG and global mean bias. We therefore adjust the emissions for winter, spring, and summer in the GMI-HiEmis simulation based on the biases and tagged tracer sensitivities for the season. We do not alter the September-December emissions since the RefGMI simulation shows little NH bias in those months (Fig. 2) and our focus is on spring and summer. We choose the adjustment factors by solving for the linear combination of $\mathrm{CO} a \mathrm{C}+\mathrm{COea}+\mathrm{COrubb}$ and COtrbb that minimizes the error in both the IHG and the global mean bias. Table 3 shows the emissions adjustments for each season. We apply the same adjustment to COaa, COea, and COrubb since these three sources show nearly the same slope (IHG bias/model bias) in Figs. 4 and 5. The purpose of this experiment is not to calculate the optimum $\mathrm{CO}$ emissions to reproduce the $\mathrm{CO}$ observations, but rather to determine how a reasonable set of $\mathrm{CO}$ emission adjustments impacts the simulated concentrations of ozone and $\mathrm{OH}$ as well as $\mathrm{CO}$.

Including larger $\mathrm{CO}$ emissions increases the loss of $\mathrm{OH}$, reducing $\mathrm{OH}$ concentrations. The mass-weighted global mean tropospheric $\mathrm{OH}$ in the GMI-HiEmis simulation is $1.11 \times 10^{6}$ molec $\mathrm{cm}^{-3}$, a $3 \%$ decrease compared to the RefGMI simulation (Table 2). The methane lifetime against tropospheric $\mathrm{OH}$ also increases slightly, from 9.6 years in the RefGMI simulation to 9.9 years in the HiEmis simulation. This slightly improves the agreement with the observationbased estimate of $11.2 \pm 1.3$ years of Prather et al. (2012). 

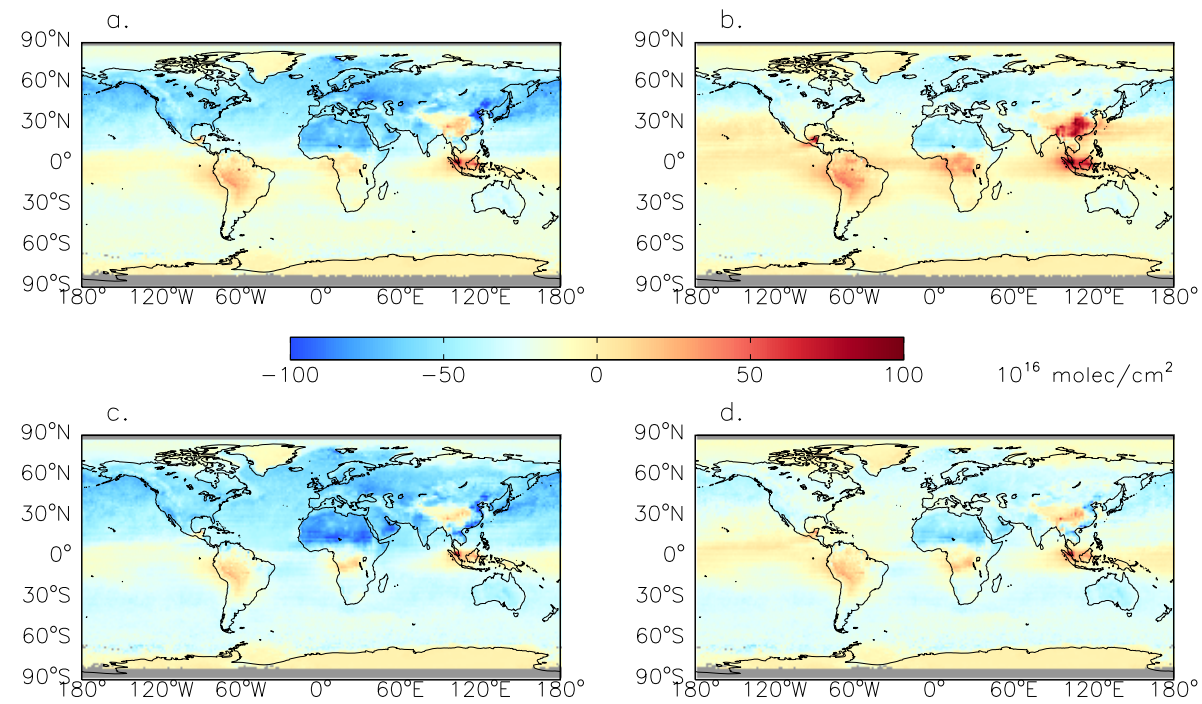

Figure 7. March through May difference between the simulated CO columns and MOPITT averaged over 2000-2009 for the (a) RefGMI, (b) GMI-HiEmis, (c) RefCOonly, and (d) COonlyLowNHOH simulations. The simulated CO is convolved with the MOPITT averaging kernels and a priori.

Table 3. CO emission adjustment for the high-emission simulation compared to the standard simulation.

\begin{tabular}{lcccc}
\hline Emission increase (\%) & \multicolumn{4}{c}{ Months } \\
\cline { 2 - 5 } & Jan-Feb & Mar-May & Jun-Aug & Sep-Dec \\
\hline Asian \& European anthropogenic; Russian BB & 17.4 & 45.0 & 63.2 & 0.00 \\
Tropical BB & 26.4 & 60.6 & 28.2 & 0.00 \\
\hline
\end{tabular}

Since the decrease in $\mathrm{OH}$ occurs primarily in the Northern Hemisphere, the NH / SH OH ratio shows a small reduction from 1.19 in the RefGMI simulation to 1.16 in the GMIHiEmis simulation, but the large hemispheric asymmetry in $\mathrm{OH}$ remains.

Both the RefGMI and GMI-HiEmis simulation show a large high bias in NH TCO compared to the OMI/MLS observations, as well as a low bias in the equatorial Pacific and the extratropical SH (Fig. 9). Similar biases were present in the ACCMIP multi-model mean (Young et al., 2013), indicating that these biases are a common feature in CCMs. The increased $\mathrm{CO}$ emissions in the GMI-HiEmis simulation slightly increase the high bias in TCO in the northern midlatitudes, but the increase is small compared to the bias in the RefGMI simulation.

\subsection{Sensitivity of OH to model biases}

Given the sensitivity of the $\mathrm{CO}$ biases to $\mathrm{OH}$ (Figs. 3, 4, and 5 ) and the relatively small changes in $\mathrm{OH}$ resulting from the increased $\mathrm{CO}$ emissions in the GMI-HiEmis simulation, we next examine how other biases in the RefGMI simulation may impact $\mathrm{OH}$ concentrations and consequently the $\mathrm{CO}$ distribution and methane lifetime. We conducted a series of sen- sitivity studies using the $\mathrm{CO}-\mathrm{OH}$ parameterization option to isolate the impact of several known model biases on $\mathrm{OH}$ and $\mathrm{CO}$ distributions. We analyze the results for the entire year in order to compare our results to observation-based estimates of methane lifetime.

The primary source of $\mathrm{OH}$ in the troposphere is ozone photolysis followed by reaction of $\mathrm{O}^{1} \mathrm{D}$ with water vapor, and secondary production of $\mathrm{OH}$ occurs through reaction of $\mathrm{HO}_{2}$ with NO or ozone (Spivakovsky et al., 2000). Consequently, simulated $\mathrm{OH}$ concentrations are sensitive to errors in $\mathrm{NO}_{x}$ and ozone concentrations, water vapor, and factors that influence photolysis such as overhead ozone column and clouds. Here, we examine the sensitivity of $\mathrm{OH}$ to model biases in some of these factors.

\subsubsection{Sensitivity to tropospheric ozone}

Comparison of output from the CCMs that participated in the ACCMIP study to OMI/MLS TCO reveals positive biases in simulated tropospheric ozone over the NH midlatitudes and negative biases over the tropical Pacific and SH (Young et al., 2013), which lead to an overestimate in NH OH production and an underestimate in SH OH production (Naik et al., 2013). The multi-model mean tropospheric ozone also shows 

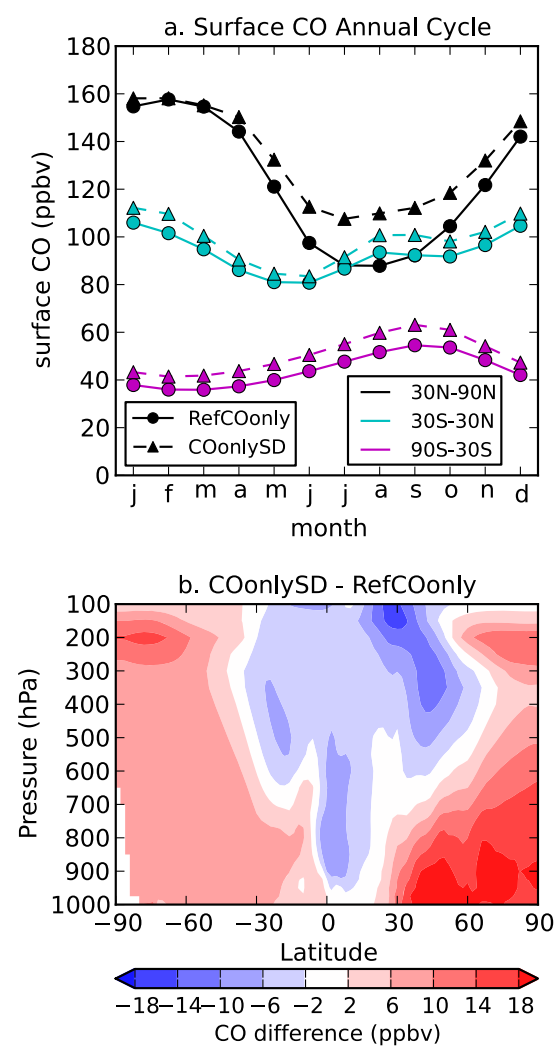

Figure 8. (a) Annual cycle of surface CO in the RefCOonly simulation (circles) and COonlySD simulation (triangles) for $30-90^{\circ} \mathrm{N}$ (black), $30^{\circ} \mathrm{S}-30^{\circ} \mathrm{N}$ (cyan), and $90-30^{\circ} \mathrm{S}$ (magenta). (b) Annual zonal mean cross section of the difference in $\mathrm{CO}$ between the COonlySD and RefCOonly simulations.

a high bias in the $\mathrm{NH}$ and low bias in the SH compared to the Tropospheric Emission Spectrometer (TES) (Bowman et al., 2013). A multi-species assimilation study by Miyazaki et al. (2012b) found that assimilating TES ozone increased OH concentrations in the $\mathrm{SH}$.

We use the $\mathrm{CO}-\mathrm{OH}$ option to investigate the impact of removing the GEOSCCM's tropospheric ozone column bias relative to the OMI/MLS observations (Fig. 9). We scale the tropospheric ozone values input to the parameterization of $\mathrm{OH}$ for each month between October 2004 and December 2010 from $60^{\circ} \mathrm{S}$ to $60^{\circ} \mathrm{N}$ so that the tropospheric ozone column is unbiased compared to the OMI/MLS TCO for that month. No scaling is applied where the TCO data are missing. We use the scaled ozone input in a sensitivity study for October 2004 to January 2010, called COOHSensTCO, which parallels the RefCO-OH simulation but uses the scaled tropospheric ozone values in the parameterization of $\mathrm{OH}$. CO-OHSensTCO shows a small (2\%) decrease in global mean $\mathrm{OH}$ compared to RefCO-OH, with a $3 \%$ decrease in $\mathrm{NH} \mathrm{OH}$ and $1 \%$ decrease in $\mathrm{SH} \mathrm{OH}$. The increased $\mathrm{OH}$ leads to a $2 \%$ increase in both methane and methyl chloroform lifetimes against $\mathrm{OH}$. The $\mathrm{NH} / \mathrm{SH} \mathrm{OH}$ ratio decreases slightly to 1.19 (Table 4), suggesting that the IHG in the tropospheric ozone bias makes only a minor contribution to the model's interhemispheric $\mathrm{OH}$ asymmetry.

\subsubsection{Sensitivity to stratospheric ozone}

We next examine how biases in stratospheric ozone affect $\mathrm{OH}$ through their role in photolysis. Voulgarakis et al. (2013) found that changes in stratospheric ozone and tropospheric $\mathrm{OH}$ in the ACCMIP models both correlated strongly with $\mathrm{J}\left(\mathrm{O}^{1} \mathrm{D}\right)$. We conduct a sensitivity study for 2005 through 2009, CO-OHSensStO3, which parallels the RefCO-OH simulation but replaces the simulated ozone with the GMAO ozone assimilation in the stratosphere for input into the parameterization. The change in global mean $\mathrm{OH}$ in $\mathrm{CO}-$ OHSensStO3 is nearly identical to that of CO-OHSensTCO, but $\mathrm{CO}-\mathrm{OHSensStO} 3$ places more of the change in the $\mathrm{SH}$, causing the $\mathrm{NH} / \mathrm{SH} \mathrm{OH}$ ratio to increase to 1.23 (Table 4). The change in $\mathrm{OH}$ due to stratospheric ozone bias is small in part because GEOSCCM has relatively small biases in tropical stratospheric ozone. However, the multi-model Chemistry Climate Model Validation-2 (CCMVal-2) study (Morgenstern et al., 2010) shows a large spread across models for column ozone in the tropics (Austin et al., 2010). Thus, biases in stratospheric ozone may play a larger role in tropospheric $\mathrm{OH}$ in models with larger stratospheric ozone biases.

\subsubsection{Sensitivity to water vapor}

We investigate the impact of model biases in water vapor on $\mathrm{OH}$ concentrations through its role in $\mathrm{OH}$ production. Intermodel differences in $\mathrm{OH}$ in the POLMIP study are correlated with inter-model differences in simulated water vapor (Monks et al., 2015). The GEOS-5 AGCM exhibits a high bias in specific humidity compared to the MERRA reanalysis in much of the troposphere (Molod et al., 2012), and a high bias in the midtroposphere is also seen throughout the year in GEOSCCM compared to Atmospheric Infrared Sounder (AIRS) data (Lamarque et al., 2013).

We quantify the impact of this bias by conducting a sensitivity study, CO-OHSensQ, that applies altitude- and latitude-dependent zonal mean scaling factors for each month to the specific humidity provided to the $\mathrm{OH}$ parameterization. The scaling factors are based on comparison of the RefGMI simulation to MERRA and are applied in $100 \mathrm{hPa}$ intervals between 900 and $200 \mathrm{hPa}$ for $60^{\circ} \mathrm{S}$ to $60^{\circ} \mathrm{N}$. These scaling factors are designed to remove the mean bias in the simulated specific humidity compared to MERRA while allowing the simulated water vapor to vary in space and time in a manner consistent with the simulated meteorology. The water vapor scaling is applied only to the $\mathrm{OH}$ parameterization and does not impact the general circulation of the simulation. The scaling results in lower specific humidity in the middle and upper troposphere, with the largest percent reductions occurring between 300 and $500 \mathrm{hPa}$ (Fig. 10). 

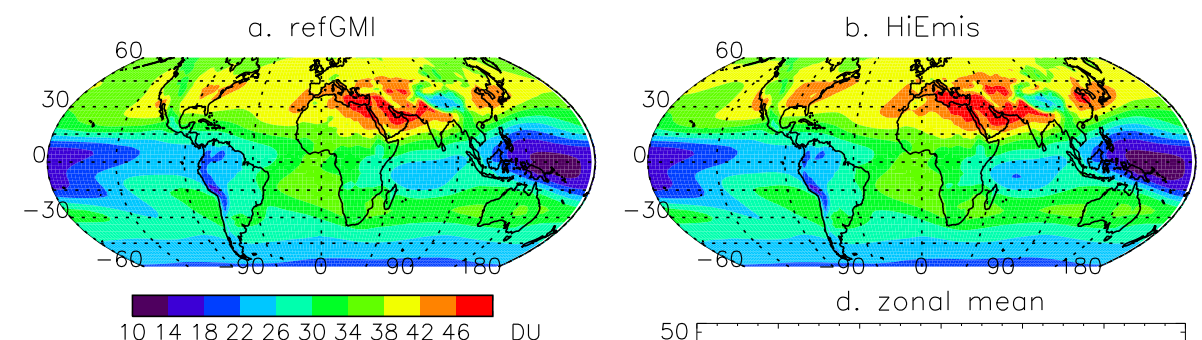

d. zonal mean
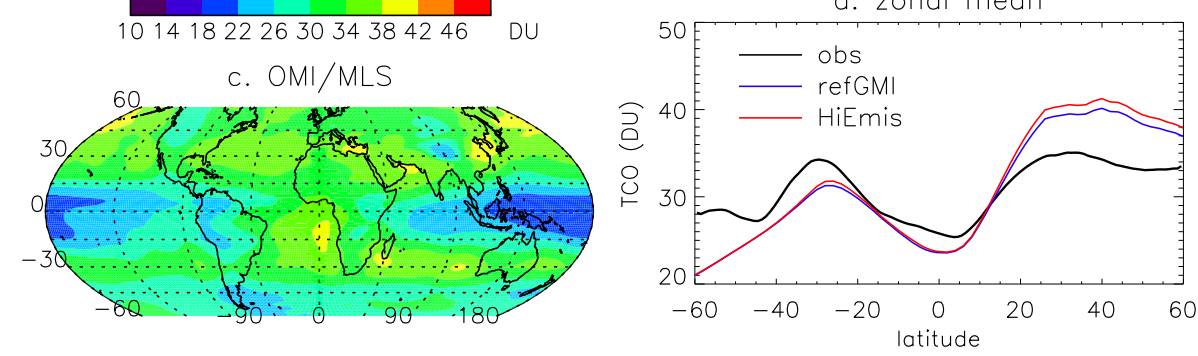

Figure 9. Annual mean tropospheric column ozone (TCO) from the RefGMI (a) and GMI-HiEmis (b) simulations compared to the OMI/MLS TCO product (c) of Ziemke et al. (2011). Panel (d) compares the zonal mean simulated and OMI/MLS values. The simulated values are averaged over the years of the time slice (1999-2009).

Table 4. $\mathrm{NH}$ / $\mathrm{SH} \mathrm{OH}$ ratio and percent changes in tropospheric $\mathrm{OH}$ concentrations and lifetimes against tropospheric $\mathrm{OH}$ for the $\mathrm{CO}-\mathrm{OH}$ sensitivity studies compared to the RefCO-OH simulation.

\begin{tabular}{lrrrrr}
\hline & SensTCO & SensStO3 & SensQ & SensNOx & SensAll \\
\hline $\mathrm{NH} / \mathrm{SH} \mathrm{OH}$ & 1.19 & 1.23 & 1.22 & 1.15 & 1.14 \\
\hline$\%$ change vs. RefCO-OH & & & & & \\
\hline Global mean OH & -2.1 & -2.1 & -6.2 & -3.1 & -13 \\
$\mathrm{SH} \mathrm{OH}$ & -1 & -2.9 & -6.3 & -0.3 & -10 \\
$\mathrm{NH} \mathrm{OH}$ & -3.1 & -1.5 & -6.1 & -5.7 & -16 \\
$\mathrm{CH}_{4}$ lifetime & 2.5 & 2.4 & 5.7 & 3.5 & 15 \\
$\mathrm{CH}_{3} \mathrm{CCl}_{3}$ lifetime & 2.4 & 2.3 & 5.9 & 3.5 & 15 \\
\hline
\end{tabular}

Simulated $\mathrm{OH}$ is $6 \%$ lower in the $\mathrm{CO}-\mathrm{OHSens}$ simulation than the RefCO-OH simulation, and the methane and methyl chloroform lifetimes against $\mathrm{OH}$ are thus $6 \%$ longer (Table 4). Consequently, water vapor bias has a larger impact on $\mathrm{OH}$ concentrations than the stratospheric or tropospheric ozone biases in our simulations. The $\mathrm{OH}$ reduction is similar in both hemispheres in the annual mean, so the $\mathrm{NH} / \mathrm{SH} \mathrm{OH}$ gradient is unchanged compare to $\mathrm{RefCO}-\mathrm{OH}$.

\subsubsection{Sensitivity to $\mathrm{NO}_{x}$}

Anthropogenic $\mathrm{NO}_{x}$ emissions, which contribute to secondary production of $\mathrm{OH}$, are located primarily in the Northern Hemisphere. Consequently, an overestimate of these emissions could contribute to the NH-SH asymmetry in simulated $\mathrm{OH}$. Previous studies have estimated $\mathrm{NO}_{x}$ emissions based on satellite observations of $\mathrm{NO}_{2}$ columns (Lamsal et al., 2011; Miyazaki et al., 2012a), but some uncertainty in $\mathrm{NO}_{x}$ emissions remains. We quantify the sensitivity of simulated $\mathrm{OH}$ to $\mathrm{NH} \mathrm{NO}_{x}$ with a sensitivity study, COOHSensNOx, which parallels RefCO-OH but includes $30 \%$ lower $\mathrm{NO}$ and $\mathrm{NO}_{2}$ concentrations in the $\mathrm{NH}$. We note that in this experiment ozone values remain the same as in RefCO$\mathrm{OH}$, rather than responding to the change in $\mathrm{NO}_{x}$. The reduction in $\mathrm{NH} \mathrm{NO}_{x}$ emissions leads to a $3 \%$ reduction in global $\mathrm{OH}$ (Table 4). SH and $\mathrm{NH} \mathrm{OH}$ are reduced by $0.3 \%$ and $6 \%$, respectively, reducing the $\mathrm{NH} / \mathrm{SH} \mathrm{OH}$ ratio to 1.15 . While this shows that the hemispheric asymmetry in $\mathrm{OH}$ is affected by $\mathrm{NO}_{x}$ emissions, a much larger redistribution of $\mathrm{NO}_{x}$ emissions would be required to completely eliminate the asymmetry.

\subsubsection{Summary of $\mathrm{OH}$ sensitivities}

In the previous sections, we examined the sensitivity of $\mathrm{OH}$ and its IHG to model biases in tropospheric and stratospheric ozone, water vapor, and $\mathrm{NH} \mathrm{NO}_{x}$ emissions. We find that water vapor has the largest impact on global mean $\mathrm{OH}$, while $\mathrm{NH} \mathrm{NO} \mathrm{N}_{x}$ emissions have the largest impact on the $\mathrm{NH} / \mathrm{SH}$ ratio. However, none of these biases individually explains the $20 \%$ reduction in $\mathrm{NH} \mathrm{OH}$ that would remove the interhemispheric asymmetry and which Figs. 4 and 5 suggest are nec- 


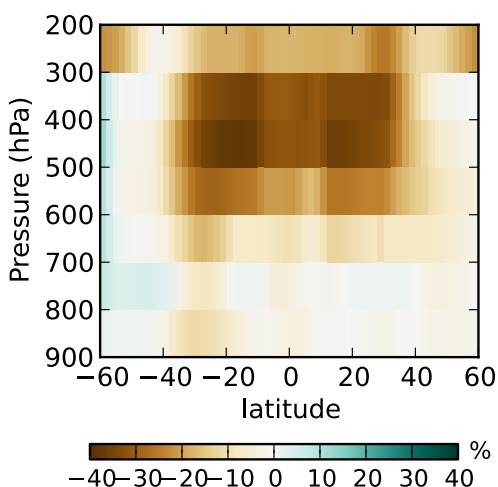

Figure 10. Annual mean percent change in specific humidity imposed in the CO-OHSensQ experiment between 900 and $200 \mathrm{hPa}$, $60^{\circ} \mathrm{S}-60^{\circ} \mathrm{N}$.

essary to remove most of the $\mathrm{CO}$ bias. We note, however, that the $\mathrm{CO}-\mathrm{OH}$ option simulations do not account for all the chemical feedbacks between ozone, methane, $\mathrm{OH}$, and other species, and they may underestimate the sensitivity of the full chemistry simulation to some of these biases.

Table 4 suggests that applying multiple bias corrections simultaneously would bring our simulation into good agreement with the observation-based estimates of global mean $\mathrm{OH}$. We conduct a final sensitivity simulation, called $\mathrm{CO}$ OHSensAll, incorporating the bias corrections for tropospheric and stratospheric ozone, as well as the specific humidity scaling and $30 \%$ reduction in $\mathrm{NH} \mathrm{NO}_{x}$ emissions. This simulation results in a $13 \%$ reduction in global mean $\mathrm{OH}$, with a $10 \%$ reduction in the $\mathrm{SH}$ and $16 \%$ reduction in the NH. The NH / SH OH ratio is reduced to 1.14. The lifetimes of methyl chloroform and methane in this simulation increase by $15 \%$. Applying this $15 \%$ increase in methane lifetime to the RefGMI methane lifetime against $\mathrm{OH}$ of 9.6 years would yield a lifetime of 11 years, consistent with the $11.2 \pm 1.3$ year estimate of Prather et al. (2012). This shows that removing the main model biases related to $\mathrm{OH}$ production would bring simulated global mean $\mathrm{OH}$ into good agreement with observation-based estimates, although some $\mathrm{NH}-$ SH asymmetry would remain.

The reduction in $\mathrm{OH}$ in the sensitivity studies compared to RefCO-OH leads to higher surface concentrations of $\mathrm{CO}$. The bias in the global mean March-August surface $\mathrm{CO}$ changes from $-4 \%$ in RefCO-OH to $3 \%$ in CO-OHSensAll, while the bias in the IHG changes from -11 to $-4 \%$. Figure 11 shows the latitudinal distribution of the change in $\mathrm{CO}$ for each sensitivity simulation versus RefCO-OH. The sum of the changes for CO-OHSensTCO, CO-OHSensStO3, $\mathrm{CO}-\mathrm{OHSens}$, and CO-OHSensNOx, shown as the dotted line, is similar but slightly smaller than the change for $\mathrm{CO}-$ OHSensAll, indicating small nonlinearities in the system. Correcting water vapor (CO-OHSensQ) makes a large contribution to the $\mathrm{CO}$ enhancement in both hemispheres, while adjusting $\mathrm{NO}_{x}$ emissions (CO-OHSensNOx) and to a lesser

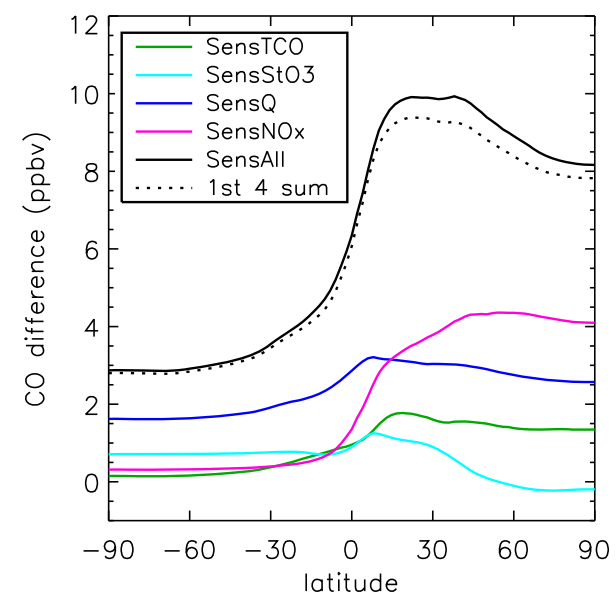

Figure 11. Zonal mean surface $\mathrm{CO}$ difference compared to RefCO-OH for the CO-OHSensTCO (green), CO-OHSensStO3 (cyan), CO-OHSensQ (blue), CO-OHSensNOx (pink), and $\mathrm{CO}-$ OHSensAll (solid black) simulations averaged over March through August of 2005 to 2009. The sum of the differences for the $\mathrm{CO}-\mathrm{OHSensTCO}, \mathrm{CO}-\mathrm{OHSensStO} 3$, CO-OHSensQ, and COOHSensNOx compared to RefCO-OH is shown as the black dotted line.

extent tropospheric ozone (CO-OHSensTCO) contributes to the larger increase in the Northern Hemisphere.

\section{Conclusions}

We examined possible causes of $\mathrm{CO}$ model bias, such as underestimated emissions or overestimated $\mathrm{OH}$, in a global CCM. An underestimate of $\mathrm{CO}$ emissions can impact the chemistry-climate simulation through the interaction of $\mathrm{CO}$ with methane via $\mathrm{OH}$ and with ozone, but we find the effects to be small. In contrast, a $\mathrm{CO}$ bias due to excess $\mathrm{OH}$ would imply biases in methane lifetime, further influencing the simulated climate.

Either increasing emissions or decreasing Northern Hemisphere $\mathrm{OH}$ can remove the bias in the latitudinal gradient of CO compared to surface observations. However, we find that the large increases in Asian anthropogenic emissions needed to remove the negative $\mathrm{CO}$ bias at remote surface sites leads to overestimates of $\mathrm{CO}$ over Asia compared to MOPITT. In contrast, reducing $\mathrm{OH}$ in the Northern Hemisphere improves the agreement between simulated and observed $\mathrm{CO}$ concentrations. This is consistent with the finding of Patra et al. (2014) that the ratio of Northern Hemisphere to Southern Hemisphere $\mathrm{OH}$ is close to 1 . We note that biases in $\mathrm{OH}, \mathrm{CO}$ emissions, and transport are not mutually exclusive, and the model bias in $\mathrm{CO}$ is likely influenced by a combination of these factors.

The availability of satellite-based constraints on CO, ozone, and water vapor enables us to assess model biases that affect the major sources and sinks of $\mathrm{OH}$ and hence $\mathrm{CO}$ con- 
centrations and methane lifetime. We used a $\mathrm{CO}-\mathrm{OH}$ parameterization to explore the effect of model biases in ozone and water vapor on simulated $\mathrm{OH}$ and $\mathrm{CO}$. Removing the high bias in Northern Hemisphere tropospheric ozone, a common feature of CCMs, had only a small effect on simulated $\mathrm{OH}$ and methane lifetime. A high bias in water vapor had a larger impact on global mean $\mathrm{OH}$, but removing this bias did not remove the $\mathrm{NH}-\mathrm{SH}$ asymmetry in $\mathrm{OH}$. Removing both ozone and water vapor biases, as well as decreasing Northern Hemisphere $\mathrm{NO}_{x}$, provided the desired increase in methane lifetime but was insufficient to remove the hemispheric asymmetry in $\mathrm{OH}$. Thus, while a NH / $\mathrm{SH} \mathrm{OH}$ ratio near 1 improves the simulation of $\mathrm{CO}$, we cannot generate this ratio in our simulations by removing known model biases in ozone and water vapor.

Our study suggests that the springtime low bias in $\mathrm{CO}$ at northern latitudes often seen in CCM simulations likely indicates a bias in methane lifetime. Improving the model representation of water vapor and ozone, as well as reducing uncertainty in $\mathrm{NO}_{x}$ emissions, could reduce these biases. However, additional research is needed to understand the causes of NH-SH asymmetry in simulated $\mathrm{OH}$. Future field missions that provide data on the latitudinal distribution of $\mathrm{CO}$ and oxidant sources and losses will be valuable for understanding biases in simulated $\mathrm{CO}$ and $\mathrm{OH}$.

Acknowledgements. Support for this work comes from NASA's Modeling, Analysis, and Prediction Program. Computing resources were provided by the NASA High-End Computing (HEC) Program.

Edited by: P. Jöckel

\section{References}

Arellano, A. F. and Hess, P. G.: Sensitivity of top-down estimates of CO sources to GCTM transport, Geophys. Res. Lett., 33, L21807, doi:10.1029/2006g1027371, 2006.

Austin, J., Scinocca, J., Plummer, D., Oman, L., Waugh, D., Akiyoshi, H., Bekki, S., Braesicke, P., Butchart, N., Chipperfield, M., Cugnet, D., Dameris, M., Dhomse, S., Eyring, V., Frith, S., Garcia, R. R., Garny, H., Gettelman, A., Hardiman, S. C., Kinnison, D., Lamarque, J. F., Mancini, E., Marchand, M., Michou, M., Morgenstern, O., Nakamura, T., Pawson, S., Pitari, G., Pyle, J., Rozanov, E., Shepherd, T. G., Shibata, K., Teyssedre, H., Wilson, R. J., and Yamashita, Y.: Decline and recovery of total column ozone using a multimodel time series analysis, J. Geophys. Res.-Atmos., 115, L21807, doi:10.1029/2010jd013857, 2010.

Berntsen, T. K., Fuglestvedt, J. S., Joshi, M. M., Shine, K. P., Stuber, N., Ponater, M., Sausen, R., Hauglustaine, D. A., and Li, L.: Response of climate to regional emissions of ozone precursors: sensitivities and warming potentials, Tellus B, 57, 283-304, doi:10.1111/j.1600-0889.2005.00152.x, 2005.

Bian, H. S., Chin, M. A., Kawa, S. R., Yu, H. B., Diehl, T., and Kucsera, T.: Multiscale carbon monoxide and aerosol correlations from satellite measurements and the GOCART model: Im- plication for emissions and atmospheric evolution, J. Geophys. Res.-Atmos., 115, D07302, doi:10.1029/2009jd012781, 2010.

Bloom, S. C., Takacs, L. L., da Silva, A. M., and Ledvina, D.: Data Assimilation Using Incremental Analysis Updates, Mon. Weather Rev., 124, 1256-1271, doi:10.1175/15200493(1996)124<1256:DAUIAU>2.0.CO;2, 1996.

Bowman, K. and Henze, D. K.: Attribution of direct ozone radiative forcing to spatially resolved emissions, Geophys. Res. Lett., 39, L22704, doi:10.1029/2012g1053274, 2012.

Bowman, K. W., Shindell, D. T., Worden, H. M., Lamarque, J.F., Young, P. J., Stevenson, D. S., Qu, Z., de la Torre, M., Bergmann, D., Cameron-Smith, P. J., Collins, W. J., Doherty, R., Dalsøren, S. B., Faluvegi, G., Folberth, G., Horowitz, L. W., Josse, B. M., Lee, Y. H., MacKenzie, I. A., Myhre, G., Nagashima, T., Naik, V., Plummer, D. A., Rumbold, S. T., Skeie, R. B., Strode, S. A., Sudo, K., Szopa, S., Voulgarakis, A., Zeng, G., Kulawik, S. S., Aghedo, A. M., and Worden, J. R.: Evaluation of ACCMIP outgoing longwave radiation from tropospheric ozone using TES satellite observations, Atmos. Chem. Phys., 13, 40574072, doi:10.5194/acp-13-4057-2013, 2013.

Daniel, J. S. and Solomon, S.: On the climate forcing of carbon monoxide, J. Geophys. Res.-Atmos., 103, 13249-13260, doi:10.1029/98jd00822, 1998.

Deeter, M. N., Worden, H. M., Gille, J. C., Edwards, D. P., Mao, D., and Drummond, J. R.: MOPITT multispectral CO retrievals: Origins and effects of geophysical radiance errors, J. Geophys. Res.-Atmos., 116, D15303, doi:10.1029/2011jd015703, 2011.

Deeter, M. N., Martinez-Alonso, S., Edwards, D. P., Emmons, L. K., Gille, J. C., Worden, H. M., Pittman, J. V., Daube, B. C., and Wofsy, S. C.: Validation of MOPITT Version 5 thermalinfrared, near-infrared, and multispectral carbon monoxide profile retrievals for 2000-2011, J. Geophys. Res.-Atmos., 118, 6710-6725, doi:10.1002/jgrd.50272, 2013.

Derwent, R. G., Collins, W. J., Johnson, C. E., and Stevenson, D. S.: Transient behaviour of tropospheric ozone precursors in a global 3-D CTM and their indirect greenhouse effects, Climatic Change, 49, 463-487, doi:10.1023/a:1010648913655, 2001.

Duncan, B. N. and Logan, J. A.: Model analysis of the factors regulating the trends and variability of carbon monoxide between 1988 and 1997, Atmos. Chem. Phys., 8, 7389-7403, doi:10.5194/acp-8-7389-2008, 2008.

Duncan, B., Portman, D., Bey, I., and Spivakovsky, C.: Parameterization of $\mathrm{OH}$ for efficient computation in chemical tracer models, J. Geophys. Res.-Atmos., 105, 12259-12262, doi:10.1029/1999jd901141, 2000.

Duncan, B. N., Logan, J. A., Bey, I., Megretskaia, I. A., Yantosca, R. M., Novelli, P. C., Jones, N. B., and Rinsland, C. P.: Global budget of CO, 1988-1997: Source estimates and validation with a global model, J. Geophys. Res.-Atmos., 112, D22301, doi:10.1029/2007jd008459, 2007a.

Duncan, B. N., Strahan, S. E., Yoshida, Y., Steenrod, S. D., and Livesey, N.: Model study of the cross-tropopause transport of biomass burning pollution, Atmos. Chem. Phys., 7, 3713-3736, doi:10.5194/acp-7-3713-2007, 2007b.

Edwards, D. P., Emmons, L. K., Hauglustaine, D. A., Chu, D. A., Gille, J. C., Kaufman, Y. J., Petron, G., Yurganov, L. N., Giglio, L., Deeter, M. N., Yudin, V., Ziskin, D. C., Warner, J., Lamarque, J. F., Francis, G. L., Ho, S. P., Mao, D., Chen, J., Grechko, E. I., and Drummond, J. R.: Observations of car- 
bon monoxide and aerosols from the Terra satellite: Northern Hemisphere variability, J. Geophys. Res.-Atmos., 109, D24202, doi:10.1029/2004jd004727, 2004.

Emmons, L. K., Deeter, M. N., Gille, J. C., Edwards, D. P., Attie, J. L., Warner, J., Ziskin, D., Francis, G., Khattatov, B., Yudin, V., Lamarque, J. F., Ho, S. P., Mao, D., Chen, J. S., Drummond, J., Novelli, P., Sachse, G., Coffey, M. T., Hannigan, J. W., Gerbig, C., Kawakami, S., Kondo, Y., Takegawa, N., Schlager, H., Baehr, J., and Ziereis, H.: Validation of Measurements of Pollution in the Troposphere (MOPITT) CO retrievals with aircraft in situ profiles, J. Geophys. Res.-Atmos., 109, D03309, doi:10.1029/2003jd004101, 2004.

Fortems-Cheiney, A., Chevallier, F., Pison, I., Bousquet, P., Szopa, S., Deeter, M. N., and Clerbaux, C.: Ten years of CO emissions as seen from Measurements of Pollution in the Troposphere (MOPITT), J. Geophys. Res.-Atmos., 116, D05304, doi:10.1029/2010jd014416, 2011.

Fry, M. M., Naik, V., West, J. J., Schwarzkopf, M. D., Fiore, A. M., Collins, W. J., Dentener, F. J., Shindell, D. T., Atherton, C., Bergmann, D., Duncan, B. N., Hess, P., MacKenzie, I. A., Marmer, E., Schultz, M. G., Szopa, S., Wild, O., and Zeng, G.: The influence of ozone precursor emissions from four world regions on tropospheric composition and radiative climate forcing, J. Geophys. Res.-Atmos., 117, D07306, doi:10.1029/2011jd017134, 2012.

Fry, M. M., Schwarzkopf, M. D., Adelman, Z., Naik, V., Collins, W. J., and West, J. J.: Net radiative forcing and air quality responses to regional $\mathrm{CO}$ emission reductions, Atmos. Chem. Phys., 13, 5381-5399, doi:10.5194/acp-13-5381-2013, 2013.

Fuglestvedt, J. S., Isaksen, I. S. A., and Wang, W. C.: Estimates of indirect global warming potentials for $\mathrm{CH}_{4}, \mathrm{CO}$ AND $\mathrm{NO}_{x}$, Climatic Change, 34, 405-437, doi:10.1007/bf00139300, 1996.

Holloway, T., Levy, H., and Kasibhatla, P.: Global distribution of carbon monoxide, J. Geophys. Res.-Atmos., 105, 12123-12147, doi:10.1029/1999jd901173, 2000.

Holmes, C. D., Prather, M. J., Søvde, O. A., and Myhre, G.: Future methane, hydroxyl, and their uncertainties: key climate and emission parameters for future predictions, Atmos. Chem. Phys., 13, 285-302, doi:10.5194/acp-13-285-2013, 2013.

Hooghiemstra, P. B., Krol, M. C., Meirink, J. F., Bergamaschi, P., van der Werf, G. R., Novelli, P. C., Aben, I., and Röckmann, T.: Optimizing global $\mathrm{CO}$ emission estimates using a four-dimensional variational data assimilation system and surface network observations, Atmos. Chem. Phys., 11, 4705-4723, doi:10.5194/acp-11-4705-2011, 2011.

IPCC: Climate Change: The IPCC Scientific Assessment, edited by: Houghton, J. T., Jenkins, G. J., and Ephraums, J. J., Cambridge University Press, 1990.

Johnson, C. E. and Derwent, R. G.: Relative radiative forcing consequences of global emissions of hydrocarbons, carbon monoxide and NOx from human activities estimated with a zonallyaveraged two-dimensional model, Climatic Change, 34, 439462, doi:10.1007/bf00139301, 1996.

Jones, D. B. A., Bowman, K. W., Logan, J. A., Heald, C. L., Liu, J., Luo, M., Worden, J., and Drummond, J.: The zonal structure of tropical $\mathrm{O}_{3}$ and $\mathrm{CO}$ as observed by the Tropospheric Emission Spectrometer in November 2004 - Part 1: Inverse modeling of CO emissions, Atmos. Chem. Phys., 9, 3547-3562, doi:10.5194/acp-9-3547-2009, 2009.
Kopacz, M., Jacob, D. J., Fisher, J. A., Logan, J. A., Zhang, L., Megretskaia, I. A., Yantosca, R. M., Singh, K., Henze, D. K., Burrows, J. P., Buchwitz, M., Khlystova, I., McMillan, W. W., Gille, J. C., Edwards, D. P., Eldering, A., Thouret, V., and Nedelec, P.: Global estimates of CO sources with high resolution by adjoint inversion of multiple satellite datasets (MOPITT, AIRS, SCIAMACHY, TES), Atmos. Chem. Phys., 10, 855-876, doi:10.5194/acp-10-855-2010, 2010.

Lamarque, J.-F., Shindell, D. T., Josse, B., Young, P. J., Cionni, I., Eyring, V., Bergmann, D., Cameron-Smith, P., Collins, W. J., Doherty, R., Dalsoren, S., Faluvegi, G., Folberth, G., Ghan, S. J., Horowitz, L. W., Lee, Y. H., MacKenzie, I. A., Nagashima, T., Naik, V., Plummer, D., Righi, M., Rumbold, S. T., Schulz, M., Skeie, R. B., Stevenson, D. S., Strode, S., Sudo, K., Szopa, S., Voulgarakis, A., and Zeng, G.: The Atmospheric Chemistry and Climate Model Intercomparison Project (ACCMIP): overview and description of models, simulations and climate diagnostics, Geosci. Model Dev., 6, 179-206, doi:10.5194/gmd-6-179-2013, 2013.

Lamsal, L. N., Martin, R. V., Padmanabhan, A., van Donkelaar, A., Zhang, Q., Sioris, C. E., Chance, K., Kurosu, T. P., and Newchurch, M. J.: Application of satellite observations for timely updates to global anthropogenic NOx emission inventories, Geophys. Res. Lett., 38, L05810, doi:10.1029/2010GL046476, 2011.

Logan, J. A., Prather, M. J., Wofsy, S. C., and McElroy, M. B.: Tropospheric Chemistry: A global Perspective, J. Geophys. Res.Atmos., 86, 7210-7254, 1981.

Mao, J., Fan, S., Jacob, D. J., and Travis, K. R.: Radical loss in the atmosphere from $\mathrm{Cu}-\mathrm{Fe}$ redox coupling in aerosols, Atmos. Chem. Phys., 13, 509-519, doi:10.5194/acp-13-509-2013, 2013.

Miyazaki, K., Eskes, H. J., and Sudo, K.: Global $\mathrm{NO}_{x}$ emission estimates derived from an assimilation of OMI tropospheric $\mathrm{NO}_{2}$ columns, Atmos. Chem. Phys., 12, 2263-2288, doi:10.5194/acp12-2263-2012, 2012a.

Miyazaki, K., Eskes, H. J., Sudo, K., Takigawa, M., van Weele, M., and Boersma, K. F.: Simultaneous assimilation of satellite $\mathrm{NO}_{2}$, $\mathrm{O}_{3}, \mathrm{CO}$, and $\mathrm{HNO}_{3}$ data for the analysis of tropospheric chemical composition and emissions, Atmos. Chem. Phys., 12, 95459579, doi:10.5194/acp-12-9545-2012, 2012b.

Molod, A., Takacs, L., Suarez, M., Bacmeister, J., Song, I.-S., and Eichmann, A.: The GEOS-5 atmospheric general circulation model: Mean climate and development from MERRA to Fortuna, NASA, Goddard Space Flight Center, Greenbelt, MD, 2012.

Monks, S. A., Arnold, S. R., Emmons, L. K., Law, K. S., Turquety, S., Duncan, B. N., Flemming, J., Huijnen, V., Tilmes, S., Langner, J., Mao, J., Long, Y., Thomas, J. L., Steenrod, S. D., Raut, J. C., Wilson, C., Chipperfield, M. P., Diskin, G. S., Weinheimer, A., Schlager, H., and Ancellet, G.: Multi-model study of chemical and physical controls on transport of anthropogenic and biomass burning pollution to the Arctic, Atmos. Chem. Phys., 15, 3575-3603, doi:10.5194/acp-15-3575-2015, 2015.

Morgenstern, O., Giorgetta, M. A., Shibata, K., Eyring, V., Waugh, D. W., Shepherd, T. G., Akiyoshi, H., Austin, J., Baumgaertner, A. J. G., Bekki, S., Braesicke, P., Bruhl, C., Chipperfield, M. P., Cugnet, D., Dameris, M., Dhomse, S., Frith, S. M., Garny, H., Gettelman, A., Hardiman, S. C., Hegglin, M. I., Jockel, P., Kinnison, D. E., Lamarque, J. F., Mancini, E., Manzini, E., Marchand, M., Michou, M., Nakamura, T., Nielsen, J. E., Olivie, D., Pitari, 
G., Plummer, D. A., Rozanov, E., Scinocca, J. F., Smale, D., Teyssedre, H., Toohey, M., Tian, W., and Yamashita, Y.: Review of the formulation of present-generation stratospheric chemistryclimate models and associated external forcings, J. Geophys. Res.-Atmos., 115, D00M02, doi:10.1029/2009jd013728, 2010.

Müller, J.-F. and Stavrakou, T.: Inversion of $\mathrm{CO}$ and $\mathrm{NO}_{x}$ emissions using the adjoint of the IMAGES model, Atmos. Chem. Phys., 5, 1157-1186, doi:10.5194/acp-5-1157-2005, 2005.

Murray, L. T., Logan, J. A., and Jacob, D. J.: Interannual variability in tropical tropospheric ozone and $\mathrm{OH}$ : The role of lightning, J. Geophys. Res.-Atmos., 118, 11468-11480, doi:10.1002/jgrd.50857, 2013.

Murray, L. T., Mickley, L. J., Kaplan, J. O., Sofen, E. D., Pfeiffer, M., and Alexander, B.: Factors controlling variability in the oxidative capacity of the troposphere since the Last Glacial Maximum, Atmos. Chem. Phys., 14, 3589-3622, doi:10.5194/acp-143589-2014, 2014.

Naik, V., Mauzerall, D., Horowitz, L., Schwarzkopf, M. D., Ramaswamy, V., and Oppenheimer, M.: Net radiative forcing due to changes in regional emissions of tropospheric ozone precursors, J. Geophys. Res.-Atmos., 110, D24306, doi:10.1029/2005jd005908, 2005.

Naik, V., Voulgarakis, A., Fiore, A. M., Horowitz, L. W., Lamarque, J.-F., Lin, M., Prather, M. J., Young, P. J., Bergmann, D., Cameron-Smith, P. J., Cionni, I., Collins, W. J., Dalsøren, S. B., Doherty, R., Eyring, V., Faluvegi, G., Folberth, G. A., Josse, B., Lee, Y. H., MacKenzie, I. A., Nagashima, T., van Noije, T. P. C., Plummer, D. A., Righi, M., Rumbold, S. T., Skeie, R., Shindell, D. T., Stevenson, D. S., Strode, S., Sudo, K., Szopa, S., and Zeng, G.: Preindustrial to present-day changes in tropospheric hydroxyl radical and methane lifetime from the Atmospheric Chemistry and Climate Model Intercomparison Project (ACCMIP), Atmos. Chem. Phys., 13, 5277-5298, doi:10.5194/acp-13-5277-2013, 2013.

Novelli, P. C. and Masarie, K. A.: Atmospheric Carbon Monoxide Dry Air Mole Fractions from the NOAA ESRL Carbon Cycle Cooperative Global Air Sampling Network, 1988-2013, Version: 2014-07-02, Path: ftp://aftp.cmdl.noaa.gov/data/trace_gases/co/ flask/surface/, 2014.

Patra, P. K., Krol, M. C., Montzka, S. A., Arnold, T., Atlas, E. L., Lintner, B. R., Stephens, B. B., Xiang, B., Elkins, J. W., Fraser, P. J., Ghosh, A., Hintsa, E. J., Hurst, D. F., Ishijima, K., Krummel, P. B., Miller, B. R., Miyazaki, K., Moore, F. L., Muhle, J., O/'Doherty, S., Prinn, R. G., Steele, L. P., Takigawa, M., Wang, H. J., Weiss, R. F., Wofsy, S. C., and Young, D.: Observational evidence for interhemispheric hydroxyl-radical parity, Nature, 513, 219-223, doi:10.1038/nature13721, 2014.

Petron, G., Granier, C., Khattatov, B., Yudin, V., Lamarque, J. F., Emmons, L., Gille, J., and Edwards, D. P.: Monthly CO surface sources inventory based on the 20002001 MOPITT satellite data, Geophys. Res. Lett., 31, L21107, doi:10.1029/2004g1020560, 2004.

Pison, I., Bousquet, P., Chevallier, F., Szopa, S., and Hauglustaine, D.: Multi-species inversion of $\mathrm{CH}_{4}, \mathrm{CO}$ and $\mathrm{H}_{2}$ emissions from surface measurements, Atmos. Chem. Phys., 9, 5281-5297, doi:10.5194/acp-9-5281-2009, 2009.

Prather, M. J.: Time scales in atmospheric chemistry: Theory, GWPs for $\mathrm{CH}_{4}$ and $\mathrm{CO}$, and runaway growth, Geophys. Res. Lett., 23, 2597-2600, 1996.
Prather, M. J., Holmes, C. D., and Hsu, J.: Reactive greenhouse gas scenarios: Systematic exploration of uncertainties and the role of atmospheric chemistry, Geophys. Res. Lett., 39, L09803, doi:10.1029/2012g1051440, 2012.

Prinn, R. G., Huang, J., Weiss, R. F., Cunnold, D. M., Fraser, P. J., Simmonds, P. G., McCulloch, A., Harth, C., Reimann, S., Salameh, P., O’Doherty, S., Wang, R. H. J., Porter, L. W., Miller, B. R., and Krummel, P. B.: Evidence for variability of atmospheric hydroxyl radicals over the past quarter century, Geophys. Res. Lett., 32, L07809, doi:10.1029/2004g1022228, 2005.

Rienecker, M. M., Suarez, M. J., Gelaro, R., Todling, R., Bacmeister, J., Liu, E., Bosilovich, M. G., Schubert, S. D., Takacs, L., Kim, G.-K., Bloom, S., Chen, J., Collins, D., Conaty, A., da Silva, A., Gu, W., Joiner, J., Koster, R. D., Lucchesi, R., Molod, A., Owens, T., Pawson, S., Pegion, P., Redder, C. R., Reichle, R., Robertson, F. R., Ruddick, A. G., Sienkiewicz, M., and Woollen, J.: MERRA: NASA's Modern-Era Retrospective Analysis for Research and Applications, J. Climate, 24, 3624-3648, doi:10.1175/JCLI-D-11-00015.1, 2011.

Rohrer, F. and Berresheim, H.: Strong correlation between levels of tropospheric hydroxyl radicals and solar ultraviolet radiation, Nature, 442, 184-187, 2006.

Shindell, D. T., Faluvegi, G., Stevenson, D. S., Krol, M. C., Emmons, L. K., Lamarque, J. F., Petron, G., Dentener, F. J., Ellingsen, K., Schultz, M. G., Wild, O., Amann, M., Atherton, C. S., Bergmann, D. J., Bey, I., Butler, T., Cofala, J., Collins, W. J., Derwent, R. G., Doherty, R. M., Drevet, J., Eskes, H. J., Fiore, A. M., Gauss, M., Hauglustaine, D. A., Horowitz, L. W., Isaksen, I. S. A., Lawrence, M. G., Montanaro, V., Muller, J. F., Pitari, G., Prather, M. J., Pyle, J. A., Rast, S., Rodriguez, J. M., Sanderson, M. G., Savage, N. H., Strahan, S. E., Sudo, K., Szopa, S., Unger, N., van Noije, T. P. C., and Zeng, G.: Multimodel simulations of carbon monoxide: Comparison with observations and projected near-future changes, J. Geophys. Res.Atmos., 111, D19306, doi:10.1029/2006jd007100, 2006.

Shindell, D. T., Faluvegi, G., Koch, D. M., Schmidt, G. A., Unger, N., and Bauer, S. E.: Improved Attribution of Climate Forcing to Emissions, Science, 326, 716-718, doi:10.1126/science.1174760, 2009.

Spivakovsky, C. M., Logan, J. A., Montzka, S. A., Balkanski, Y. J., Foreman-Fowler, M., Jones, D. B. A., Horowitz, L. W., Fusco, A. C., Brenninkmeijer, C. A. M., Prather, M. J., Wofsy, S. C., and McElroy, M. B.: Three-dimensional climatological distribution of tropospheric $\mathrm{OH}$ : Update and evaluation, J. Geophys. Res.Atmos., 105, 8931-8980, doi:10.1029/1999jd901006, 2000.

Stein, O., Schultz, M. G., Bouarar, I., Clark, H., Huijnen, V., Gaudel, A., George, M., and Clerbaux, C.: On the wintertime low bias of Northern Hemisphere carbon monoxide found in global model simulations, Atmos. Chem. Phys., 14, 9295-9316, doi:10.5194/acp-14-9295-2014, 2014.

Strahan, S. E., Duncan, B. N., and Hoor, P.: Observationally derived transport diagnostics for the lowermost stratosphere and their application to the GMI chemistry and transport model, Atmos. Chem. Phys., 7, 2435-2445, doi:10.5194/acp-7-2435-2007, 2007.

Strode, S. A. and Pawson, S.: Detection of carbon monoxide trends in the presence of interannual variability, J. Geophys. Res.Atmos., 118, 12257-12273, doi:10.1002/2013JD020258, 2013. 
Voulgarakis, A., Naik, V., Lamarque, J.-F., Shindell, D. T., Young, P. J., Prather, M. J., Wild, O., Field, R. D., Bergmann, D., CameronSmith, P., Cionni, I., Collins, W. J., Dalsøren, S. B., Doherty, R. M., Eyring, V., Faluvegi, G., Folberth, G. A., Horowitz, L. W., Josse, B., MacKenzie, I. A., Nagashima, T., Plummer, D. A., Righi, M., Rumbold, S. T., Stevenson, D. S., Strode, S. A., Sudo, K., Szopa, S., and Zeng, G.: Analysis of present day and future $\mathrm{OH}$ and methane lifetime in the ACCMIP simulations, Atmos. Chem. Phys., 13, 2563-2587, doi:10.5194/acp-13-25632013, 2013.

Wargan, K., Pawson, S., Olsen, M. A., Witte, J. C., Douglass, A. R., Ziemke, J. R., Strahan, S. E., and Nielsen, J. E.: The global structure of upper troposphere-lower stratosphere ozone in GEOS-5: A multiyear assimilation of EOS Aura data, J. Geophys. Res.Atmos., 120, 2013-2036, doi:10.1002/2014JD022493, 2015.

Young, P. J., Archibald, A. T., Bowman, K. W., Lamarque, J.-F., Naik, V., Stevenson, D. S., Tilmes, S., Voulgarakis, A., Wild, O., Bergmann, D., Cameron-Smith, P., Cionni, I., Collins, W. J., Dalsøren, S. B., Doherty, R. M., Eyring, V., Faluvegi, G., Horowitz, L. W., Josse, B., Lee, Y. H., MacKenzie, I. A., Nagashima, T., Plummer, D. A., Righi, M., Rumbold, S. T., Skeie, R. B., Shindell, D. T., Strode, S. A., Sudo, K., Szopa, S., and Zeng, G.: Preindustrial to end 21 st century projections of tropospheric ozone from the Atmospheric Chemistry and Climate Model Intercomparison Project (ACCMIP), Atmos. Chem. Phys., 13, 20632090, doi:10.5194/acp-13-2063-2013, 2013.
Ziemke, J. R., Chandra, S., Labow, G. J., Bhartia, P. K., Froidevaux, L., and Witte, J. C.: A global climatology of tropospheric and stratospheric ozone derived from Aura OMI and MLS measurements, Atmos. Chem. Phys., 11, 9237-9251, doi:10.5194/acp11-9237-2011, 2011.

Ziemke, J. R., Olsen, M. A., Witte, J. C., Douglass, A. R., Strahan, S. E., Wargan, K., Liu, X., Schoeberl, M. R., Yang, K., Kaplan, T. B., Pawson, S., Duncan, B. N., Newman, P. A., Bhartia, P. K., and Heney, M. K.: Assessment and applications of NASA ozone data products derived from Aura OMI/MLS satellite measurements in context of the GMI chemical transport model, J. Geophys. Res.Atmos., 119, 5671-5699, doi:10.1002/2013jd020914, 2014. 